\title{
Taxonomic Status of Lactic Acid Bacteria in Wine and Key Characteristics to Differentiate Species
}

\author{
L.M.T. Dicks* and A. Endo \\ Department of Microbiology, Stellenbosch University, Private Bag X1, 7602 Matieland (Stellenbosch), South Africa \\ Submitted for publication: March 2009 \\ Accepted for publication: May 2009 \\ Key words: Taxonomy; malolactic bacteria; key characteristics
}

\begin{abstract}
Oenococcus oeni is the best malolactic bacterium adapted to low $\mathrm{pH}$ and the high $\mathrm{SO}_{2}$ and ethanol concentrations in wine. Leuconostoc mesenteroides and Leuconostoc paramesenteroides (now classified as Weissella paramesenteroides) have also been isolated from wine. Pediococcus damnosus is not often found in wine and is considered a contaminant of high pH wines. Pediococcus inopinatus, Pediococcus parvulus and Pediococcus pentosaceus have occasionally been isolated from wines. Lactobacillus brevis, Lactobacillus plantarum, Lactobacillus buchneri, Lactobacillus hilgardii (previously Lactobacillus vermiforme), Lactobacillus fructivorans (previously Lactobacillus trichoides and Lactobacillus heterohiochii) and Lactobacillus fermentum have been isolated from most wines. Lactobacillus hilgardii and $L$. fructivorans are resistant to high acid and alcohol and have been isolated from spoiled fortified wines. Lactobacillus vini, Lactobacillus lindneri, Lactobacillus nagelii and Lactobacillus kunkeei have been described more recently. The latter two species are known to cause sluggish or stuck alcoholic fermentations in wine. Although Lactobacillus collinoides and Lactobacillus mali (previously Lactobacillus yamanashiensis) decarboxylate L-malic acid, they are more often found in cider and fruit juices. Lactobacillus curvatus, Lactobacillus delbrueckii, Lactobacillus diolivorans, Lactobacillus jensenii and Lactobacillus paracasei are seldomly isolated from wines. Some strains of Lactobacillus casei may be closer related to Lactobacillus paracasei or a distant relative, Lactobacillus zeae. Oenococcus kitaharae, isolated from compost is genetically closely related to Oenococcus oeni, but does not decarboxylate malate, prefers higher growth $\mathrm{pH}$ and is phenotypically well distinguished from $O$. oeni. This review summarises the current taxonomic status of malolactic bacteria and lists key phenotypic characteristics that may be used to identify the species.
\end{abstract}

Malolactic bacteria (MLB) convert L-malic acid to L(+)-lactic acid and $\mathrm{CO}_{2}$. The slight increase in $\mathrm{pH}$, accompanied by the fermentation of residual sugars, ensures a microbiologically stable product before bottling (Rankine, 1972; König and Fröhlich, 2009). Wines produced in cold regions, i.e. Germany, France and the Eastern United States, have a high acid content and may benefit from deacidification by malolactic fermentation (MLF). Oenococcus oeni is predominant in wines with a low $\mathrm{pH}(<3.5)$ and produces flavor compounds such as acetaldehyde, diacetyl, acetic acid, acetoin, and 2,3-butanediol (Nielsen \& Richelieu, 1999; Bartowsky \& Henschke, 2004; Swiegers et al., 2005; Unden \& Zaunmüller, 2009). Wines from warmer viticultural regions, i.e. South Africa, California and Australia, have a lower acidity (Jackson, 2008). Secondary (malolactic) fermentation (MLF) in these wines could be detrimental and a reduction of the acid level could result in a flat, insipid wine and subsequent growth of spoilage bacteria, e.g. Pediococcus damnosus and certain Lactobacillus spp. (Bartowsky \& Henschke, 2004; Swiegers et al., 2005). It is thus important to control MLF in wine and carefully select starter cultures. Several excellent reviews on MLF, of which most focus on the benefits and disadvantages, and changes in the sensory qualities of wines, have been published (Davis et al., 1985; Wibowo et al., 1985; Henick-Kling, 1988; Kunkee, 1991; Lonvaud-Funel, 1999; Swiegers et al., 2005).

Bacterial numbers increase to $10^{3}$ or $10^{4} \mathrm{cfu} / \mathrm{ml}$ soon after crushing of the grapes, but decline to almost no detectable levels during alcoholic (yeast) fermentation (Fleet, 2001). O. oeni, Leuconostoc mesenteroides subsp. mesenteroides and a number of Lactobacillus spp. are almost always present throughout primary (alcoholic) and secondary fermentations (Lonvaud-Funel, 1999; Swiegers et al., 2005; Jackson, 2008).

This review focuses on the taxonomic status of MLB within the broader family of LAB and lists key phenotypic and genotypic characteristics that may be used to distinguish MLB from other LAB. In some cases clear species differentiation can only be obtained by comparison of genotypic characteristics.

\section{THE GENUS OENOCOCCUS}

The name Oenococcus pertains to "a little round berry from wine". Only two species have been described, i.e. O. oeni and Oenococcus kitaharae. Description of the genus is based on characteristics of Leuconostoc oenos (Garvie, 1986), later reclassified to O. oeni by Dicks et al. (1995).

Oenococcus cells are Gram-positive, non-motile, asporogenous and ellipsoidal to spherical in shape, usually arranged in pairs or short chains. Cell morphology may vary, depending on growth conditions and age. Sugars are fermented via a combination of the hexose-monophosphate and phosphoketolase pathways. Glucose-6-phosphate dehydrogenase (G6PDH) and xylulose-5phosphoketolase are the key metabolic enzymes (Garvie, 1986). Equal amounts of D(-)-lactic acid, $\mathrm{CO}_{2}$, and ethanol are formed from the metabolism of D-glucose. Pentose phosphate may be converted 
to acetic acid, but depends on the level of dissolved oxygen in the medium (Garvie, 1986). NAD and NADP serve as coenzymes for G6PDH, but only NADP is required (Garvie, 1975). Energy (ATP) is obtained by substrate level phosphorilation. Catalase and cytochromes are not present. Polysaccharides and most alcohols are not metabolized. Strains are usually non-proteolytic, although exoprotease activity has been reported for a strain isolated from red wine produced in Argentina (Manca de Nadra et al., 2004). Nitrate is not reduced and indole is not formed. Growth is optimal at $\mathrm{pH}$ 4.8 , but some strains may prefer $\mathrm{pH} 6.0$ to 6.8. In general, growth is stimulated in the presence of $10 \% \mathrm{CO}_{2}$ (Garvie, 1986) Colonies on plates usually develop only after a few days and are less than 1 $\mathrm{mm}$ in diameter. Best growth is recorded between 20 and $30^{\circ} \mathrm{C}$, in a sugar and protein rich medium, supplemented with tomato juice or grape juice (Garvie, 1986).

O. oeni decarboxylates L-malate to $\mathrm{L}(+)$-lactate by using the malolactic enzyme in the presence of NAD and manganese (Radler, 1986). L-malate as sole carbon source does not support growth, suggesting that a malic enzyme and malate dehydrogenase are not present (Schütz \& Radler, 1973; Radler, 1986). MLF is regulated by glucose. As little as $2 \mathrm{mM}$ glucose inhibits MLF by $50 \%$ (Miranda et al., 1997). Similar results were recorded in the presence of galactose, trehalose, and maltose. Ribose and 2-deoxyglucose, however, had no effect on the conversion of L-malic acid (Miranda et al., 1997). Glucose inhibition is reversed by the addition of fructose or citrate, which leads to an increase in intracellular concentrations of glucose-6-phosphate, 6-phosphogluconate, and glycerol-3phosphate (Miranda et al., 1997). Phenolic compounds in red wine reduces the rate of sugar consumption by $O$. oeni, but enhances the metabolism of citric acid, which in turn leads to increased levels of acetic acid (Rozés et al., 2003). Genes encoding the malolactic enzyme and malate permease (mleA, $m l e P)$ have been sequenced (Labarre et al., 1996).

O. oeni requires as many as 13 amino acids for growth (Garvie, 1967a). Glutamic acid, valine, guanine, adenine, xanthine, uracil, riboflavin, folic acid, nicotinic acid, thiamine, biotin and pantothenic acid, or a derivative of pantothenic acid, are required by all strains (Garvie, 1967a; Garvie, 1986). Isoleucine, leucine, methionine, and tryptophan stimulates the growth of certain strains (Garvie, 1967a). Some strains grow in the absence of uracil and Tween 80 (Garvie, 1967a). None of the strains require pyridoxal (Garvie, 1967a), cobalamin, and p-aminobenzoic acid (Garvie, 1986).

$O$. oeni is distinguished from other lactic acid bacteria based on growth at $\mathrm{pH} 4.8$, resistance to ethanol, requirement for specific growth factors in tomato juice or grape juice, the lack of NADdependent G6PDH, and electrophoretic mobility of $\mathrm{D}(-)$-lactate dehydrogenase (D-LDH), G6PDH and alcohol dehydrogenase (ADH) (Garvie, 1986). Antisera prepared from O. oeni showed no cross-reactivity with anti-G6PDH and anti-D(-)-LDH of Leuconostoc lactis and anti-G6PDH of Leuconostoc mesenteroides subsp. mesenteroides (Gasser \& Hontebeyrie, 1977). Total soluble cell protein patterns recorded for $O$. oeni are unique and different from Leuconostoc spp. (Dicks, 1989, 1995; Dicks et al., 1990). Phenotypic characteristics are listed in Table 1.

O. oeni is genotypically not closely related to other LAB and shares 3-15\% DNA homology with Leuconostoc spp. (Dicks \& Holzapfel, 2009). O. oeni is also phylogenetically well separated from the Leuconostoc sensu stricto group, the Weissella
("Leuconostoc") paramesenteroides group, and all other LAB, as revealed by 16S rRNA (Martinez-Murcia \& Collins, 1990, 1991; Collins et al., 1993) and 23S rRNA (Martinez-Murcia et al., 1993) sequencing. This suggests that $O$. oeni originated from a distinct line of descent (Dicks et al., 1995). The phylogenetic relationship of $O$. oen $i$ with other LAB is shown in Fig. 1.

Type strain of $O$. oeni: ATCC 23279, CCUG 30199, CCUG 32250, CIP 106144, DSM 20252, JCM 6125, LMG 9851, NBRC 100497, NCIMB 11648, NRRL B-3472.

GenBank accession number (16S rRNA): AB022924, M35820, X95980.

O. kitaharae does not decarboxylate L-malate, does not grow in the presence of $10 \%(\mathrm{v} / \mathrm{v})$ ethanol, and does not require the tomato juice growth factor (Endo \& Okada, 2006). The species grows optimal at $\mathrm{pH} 6.0$ to 6.8 and at $30^{\circ} \mathrm{C}$ (Endo \& Okada, 2006). Other phenotypic critera that differentiates $O$. kitaharae from $O$. oeni are listed in Table 1. The two species share 96\% 16S rRNA sequence homology (Endo \& Okada, 2006).

Type strain of $O$. kitaharae: NRIC 0645, JCM 13282, DSM 17330.

GenBank accession number (16S rRNA): AB221475.

\section{Enrichment and isolation}

Growth is supported by a complex combination of amino acids, peptides, fermentable carbohydrates, fatty acids, nucleic acids and vitamins. Biotin, nicotine, thiamine, and pantothenic acids, or derivatives thereof, are required by most strains. Growth on plates is greatly enhanced by semi-anaerobic or microaerophilic incubation, i.e. in the presence of $5 \% \mathrm{CO}_{2}, \mathrm{~N}_{2}$, and $\mathrm{H}_{2}$, or in an anaerobic jar with GasPak (Oxoid, Cambridge, UK) or Anaerocult A (Merck, Darmstadt, Germany). Cysteine hydrochloride (0.05$0.1 \%, \mathrm{w} / \mathrm{v}$ ) is often added to broth media to produce microaerophilic conditions. Optimal growth occurs between 20 and $30^{\circ} \mathrm{C}$, but it may take as long as 10 days (Garvie, 1986).

Several growth media have been described for $O$. oeni, all of which are acidic with an initial $\mathrm{pH}$ between 4.8 and 5.5. The acidic tomato broth (ATB) medium described by Garvie (1967a) contains $25 \%(\mathrm{v} / \mathrm{v})$ tomato juice. A modification of the latter medium, described by Dicks et al. (1990) contains $25 \%$ (v/v) grape juice (acidic grape medium). Weiler \& Radler (1970) described a more complex medium that contains glucose, yeast extract, peptone, Tween-80, diammonium hydrogen citrate and sodium acetate (pH 5.4). Sorbic acid $(0.05 \%, \mathrm{w} / \mathrm{v}$, final concentration) is added to suppress the growth of yeast. Davis et al. (1985) preferred to use MRS (De Man et al., 1960) or tomato juice medium (Ingraham et al., 1960), adjusted to $\mathrm{pH} 5.5$ and supplemented with cycloheximide $(50 \mu \mathrm{g} / \mathrm{ml})$ to prevent yeast growth. Enhanced growth was recorded when the latter medium was supplemented with 40 to $80 \%(\mathrm{v} / \mathrm{v})$ wine (Davis et al., 1985) or apple juice (Kelly et al., 1989). The FT medium of Cavin et al. (1988) contains Tween-80, D-fructose and L-malic acid, buffered with $\mathrm{CaCl}_{2}$ and $\mathrm{KH}_{2} \mathrm{PO}_{4}$. A modification of the FT-medium, which contains low concentrations of fructose and glucose, cellulose MN 300, and bromocresol green, was used to differentiate malolactic strains from non-malolactic strains (Cavin et al., 1989). Sugar fermentation reactions may be studied by using the "sugar basal broth" described by Garvie (1984), modified by adjusting the $\mathrm{pH}$ to 5.2, and substituting bromocresol purple with bromocresol green $(0.004 \%, \mathrm{w} / \mathrm{v})$. 
Oenococcus kitaharae is less fastidious and can be cultured in MRS containing BHI (brain heart infusion) medium (Endo \& Okada, 2006).

\section{THE GENUS LEUCONOSTOC}

The name Leuconostoc pertains to "a colorless nostoc". Currently, the genus consists of eleven species (Table 2). Cells are Grampositive, catalase negative, non-motile, asporogenous and ellipsoidal or spherical. Cells grown in a glucose-rich or on a solid medium may appear elongated and thus similar to lactobacilli. Cells are either single, arranged in pairs, or form short to medium length chains. Strains of $L$. mesenteroides may produce dextran, visible as an electron-dense coat on the cell surface.

Growth on the surface of solid medium is poor, but is stimulated when incubated in the presence of $19.8 \% \mathrm{CO}_{2}, 11.4 \% \mathrm{H}_{2}$, and $78 \% \mathrm{~N}_{2}$. Growth in broth is stimulated by the addition of $0.05 \%$ (w/v) cysteine $\mathrm{HCl}$. Colonies develop usually only after three to five days, are smooth, round grayish white and less than $1 \mathrm{~mm}$ in diameter. The species are nonproteolytic and nitrate is not reduced. Indole is not formed and arginine is not hydrolyzed. Optimal growth is recorded at $\mathrm{pH} 6.5$ and between 20 and $30^{\circ} \mathrm{C}$. Growth may occur at $5^{\circ} \mathrm{C}$, but this is seldomly reported. All species require nicotinic acid, thiamine, biotin and either pantothenic acid or its derivative 4'O-( $\alpha$-glucopyranosyl)-D-pantothenic acid. Cobalamin and $\rho$-aminobenzoic acid are not required. Glucose is fermented to $\mathrm{D}(-)$-lactic acid, $\mathrm{CO}_{2}$ and ethanol, or acetate, via a combination of the hexose-monophosphate and phosphoketolase pathways. Fructose 1,6-diphosphate aldolase is absent. All species contain an active G6PDH. Xylulose 5-P phosphoketolase converts fermentable sugars to ethanol and D(-)-lactic acid. Some strains may produce additional acetate instead of ethanol when grown in the presence of oxygen. L-malate is decarboxylated to $\mathrm{L}(+)$-lactate by some strains and only in the presence of a fermentable carbohydrate. Polysaccharides and

\section{TABLE 1}

Phenotypic characteristics of Oenococcus oeni, Oenococcus kitaharae and Leuconostoc mesenteroides. ${ }^{\mathrm{a}, \mathrm{b}}$

\begin{tabular}{|c|c|c|c|c|c|}
\hline Characteristic & O. oeni & O. kitaharae & $\begin{array}{c}\text { L. mesenteroides subsp. } \\
\text { mesenteroides }\end{array}$ & $\begin{array}{c}\text { L. mesenteroides subsp. } \\
\text { dextranicum }\end{array}$ & $\begin{array}{l}\text { L. mesenteroides subsp. } \\
\text { cremoris }\end{array}$ \\
\hline \multicolumn{6}{|l|}{ Acid from: } \\
\hline Arabinose & $\mathrm{d}$ & - & + & - & - \\
\hline Arbutin & ND & ND & $\mathrm{d}$ & - & - \\
\hline Cellobiose & $\mathrm{d}$ & $\mathrm{d}$ & $\mathrm{d}$ & - & - \\
\hline Cellulose & $\mathrm{d}$ & ND & $\mathrm{d}$ & $\mathrm{d}$ & - \\
\hline Fructose & + & + & + & + & - \\
\hline Galactose & $\mathrm{d}$ & + & + & $\mathrm{d}$ & + \\
\hline Lactose & - & - & $\mathrm{d}$ & + & $\mathrm{d}$ \\
\hline Maltose & - & + & + & + & - \\
\hline Mannitol & - & - & $\mathrm{d}$ & - & - \\
\hline Mannose & $\mathrm{d}$ & + & $\mathrm{d}$ & $\mathrm{d}$ & - \\
\hline Melibiose & $\mathrm{d}$ & + & $\mathrm{d}$ & $\mathrm{d}$ & - \\
\hline Raffinose & - & $(+)$ & $\mathrm{d}$ & $\mathrm{d}$ & - \\
\hline Ribose & $\mathrm{d}$ & $(+)$ & $\mathrm{d}$ & + & - \\
\hline Salicin & $\mathrm{d}$ & $\mathrm{d}$ & $\mathrm{d}$ & - & - \\
\hline Sucrose & - & - & + & + & - \\
\hline Trehalose & + & + & + & + & - \\
\hline Xylose & $\mathrm{d}$ & - & $\mathrm{d}$ & $\mathrm{d}$ & - \\
\hline Hydrolysis of esculin & + & ND & + & + & - \\
\hline Dextran production & - & - & + & + & - \\
\hline Growth at $\mathrm{pH} 4.8$ & + & $\mathrm{d}$ & - & - & - \\
\hline Requirement of TJF & $\mathrm{d}$ & - & - & - & - \\
\hline Growth in $10 \%$ ethanol & + & - & - & - & - \\
\hline NAD-dependent G6PDH ${ }^{c}$ & - & ND & + & + & + \\
\hline Growth at $37 \mathrm{C}$ & $\mathrm{d}$ & - & $\mathrm{d}$ & + & - \\
\hline Peptidoglycan type & $\begin{array}{l}\text { Lys-Ser }{ }_{2} \text { or } \\
\text { Lys-Ala-Ser }\end{array}$ & ND & Lys-Ser-Ala ${ }_{2}$ & Lys-Ser-Ala ${ }_{2}$ & Lys-Ser-Ala ${ }_{2}$ \\
\hline
\end{tabular}

a+, $90 \%$ or more of strains positive; -, $90 \%$ or more of strains negative; d, 11-98\% of strains positive; (), delayed reaction; ND, no data; D, $90 \%$ or more of the lactic acid is $\mathrm{D}(-)$. Data from Dicks \& Holzapfel (2009).

${ }^{\mathrm{b}}$ Arginine hydrolysis: negative for all species. All species produce $\mathrm{CO}_{2}, \mathrm{D}(-)$ lactic acid and ethanol or acetic acid from $\mathrm{D}$-glucose.

${ }^{\mathrm{c}}$ Glucose-6-phosphate dehydrogenase. 


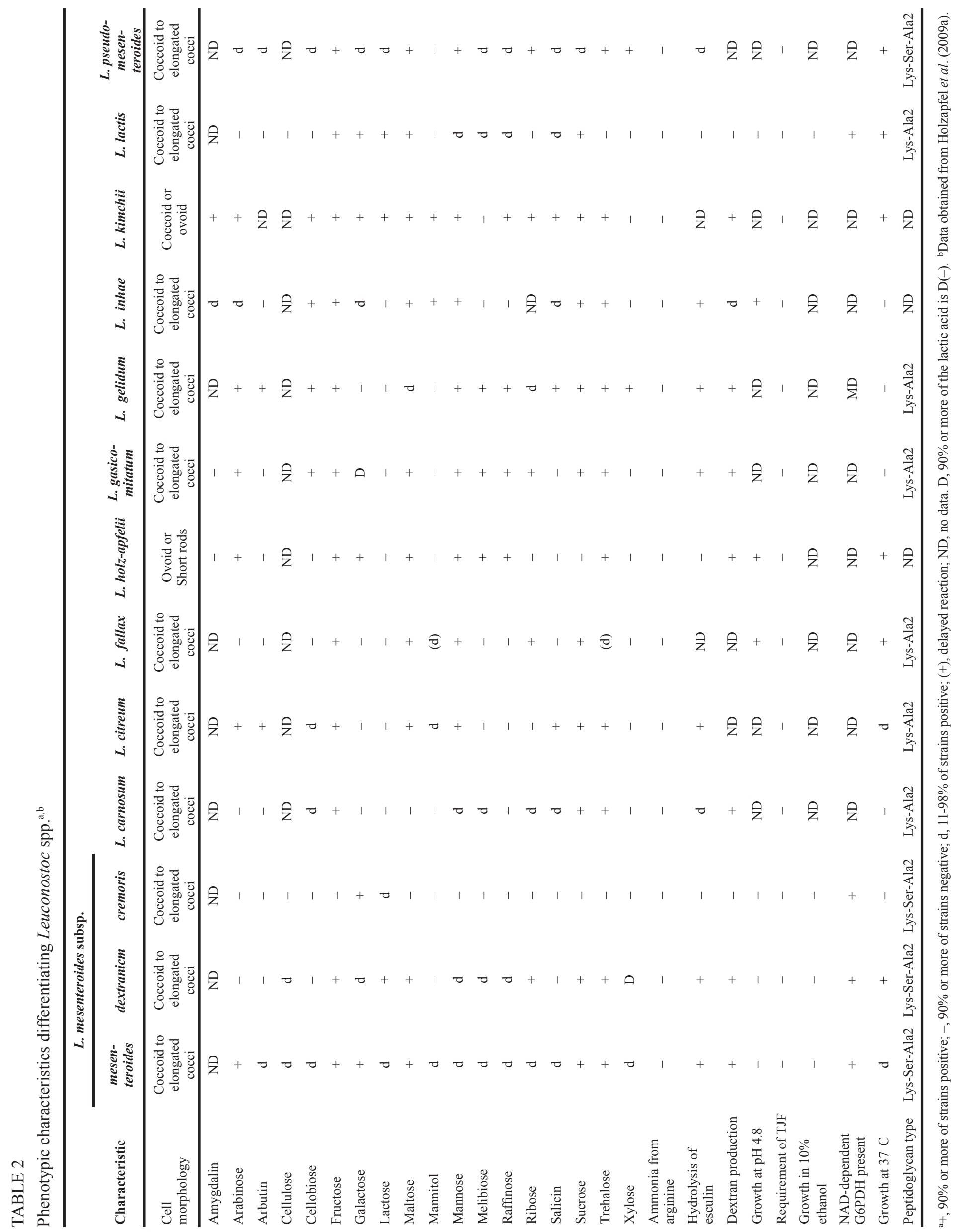


alcohols, except mannitol, are not metabolized. Carbohydrate fermentation patterns vary considerably among Leuconostoc spp. (Table 2) and are often strain dependent. Certain strains of Leuconostoc, when grown under acidic conditions, ferment sucrose (Garvie, 1967b). Nonpolysaccharide-producing strains of L. mesenteroides form dextran in media containing tomato juice or orange juice (Pederson \& Albury, 1955; Langston \& Bouma, 1959). Key phenotypic characteristics that are used to differentiate Leuconostoc spp. from other LAB is shown in Table 3.

Leuconostoc spp. are clearly differentiated based on their soluble cell protein profiles and DNA homology (Dicks et al., 1990, 1993). Numerical analysis of 16 and 23S rDNA gene RFLP patterns is also used to differentiate species. Digestion with HindIII yielded species-specific patterns (Björkroth et al., 2003). The phylogenetic relationship among Leuconostoc spp. is shown in Fig. 1. Since L. mesenteroides is the main species present in wine, the characteristrics of only the three subspecies are discussed. For the sake of simplicity Weissella paramesenteroides (previously Leuconostoc paramesenteroides) is included in the same section as Leuconostoc. Leuconostoc durionis, Leuconostoc ficulneum and Leuconostoc fructosum have been reclassified as Fructobacillus durionis, Fructobacillus ficulneus and Fructobacillus fructosus, respectively (Endo and Okada, 2008) and are not included in this review. A detailed description for each of the Leuconostoc sp. and Weissella paramesenteroides can be found in Holzapfel et al. (2009a) and Björkroth et al. (2009), respectively.

\section{Leuconostoc mesenteroides subsp. mesenteroides}

Some strains convert L-malate to L-lactate. Dextran is produced from the fermentation of sucrose, especially when incubated between $20^{\circ} \mathrm{C}$ and $25^{\circ} \mathrm{C}$. Colonies are not uniform on sucrose agar and depend on the chemical structure of the dominant type of dextran formed. Some strains produce a heme-requiring catalase (Whittenbury, 1964). Growth has been recorded in the presence of $3.0 \%(\mathrm{w} / \mathrm{v})$ and $6.5 \%(\mathrm{w} / \mathrm{v}) \mathrm{NaCl}$. Milk supplemented with yeast extract and glucose is acidified and curdled, but not by all strains. Glutamic acid and valine are required. Sugar fermentation reactions are listed in Table 2.

Type strain: Strain 12954, ATCC 8293, DSM 20343, CCUG 30066, CIP 102305, HAMBI 2347, JCM 6124, LMG 6893, NBRC 100496, NRRL B-1118, NRRL B-3470, VKM B-1601.

GenBank accession number (16S rRNA): M23035.

\section{Leuconostoc mesenteroides subsp. cremoris}

Cells may form long chains with resultant flocculent growth in broth. Dextran is not produced from the fermentation of sucrose. Citrate is metabolized to acetoin and diacetyl (Speckman \& Collins, 1968). Most strains do not ferment sucrose (Whittenbury, 1966). Compared to the other two subspecies, a limited number of carbohydrates are fermented (Table 2). Growth is optimal between $18^{\circ} \mathrm{C}$ and $25^{\circ} \mathrm{C}$. All known strains have been isolated from dairy products.

Type strain: ATCC 19254, CCUG 21965, CIP 103009, DSM 20346, LMG 6909, NCIMB 12008, NRRL B-3252, VKM B-1420.

GenBank accession number (16S rRNA): M23034.

\section{Leuconostoc mesenteroides subsp. dextranicum}

Dextran is produced from sucrose, but less actively than by $L$. mesenteroides subsp. mesenteroides. Fewer carbohydrates are fermented than by L. mesenteroides subsp. mesenteroides (Table 2). More amino acids and vitamins are required for growth than are required by $L$. mesenteroides subsp. mesenteroides. Growth occurs from $10^{\circ} \mathrm{C}$ to $37^{\circ} \mathrm{C}$ (optimum, $20-30^{\circ} \mathrm{C}$ ). Glucose litmus milk is acidified and curdled and gas production may be formed but not by all strains.

Type strain: ATCC 19255, CCUG 21966, CCUG 30065, CIP 102423, DSM 20484, JCM 9700, LMG 6908, NCIMB 12007, NBRC 100495, NCAIM B.01658, NCIMB 12007, NRRL B-3469, VKM B-1225.

GenBank accession number (16S rRNA): AB023246.

\section{Weissella paramesenteroides (previously Leuconostoc parames-} enteroides)

The cells are spherical, but often lenticular and may occur in pairs and chains. Gram-positive, non-motile, and nonsporeforming. The interpeptide bridge of the peptidoglycan structure is Lys-Ala ${ }_{2}$; LysSer-Ala ${ }_{2}$ Ammonia is not produced from arginine. Dextran is not formed from the fermentation of sucrose. Amino acid requirements are complex and vary between strains. Growth may occur at 18 $24^{\circ} \mathrm{C}$, but $30^{\circ} \mathrm{C}$ is preferred. Pseudocatalase may be formed if cells are grown in medium with low glucose concentration. Growth has been recorded in media with an initial $\mathrm{pH}$ below 5.0

Type strain: ATCC 33313, CCUG 30068, CIP 102421, DSM 20288, JCM 9890, LMG 9852, NCIMB 13092, NRIC 1542, NRRL B-1186, NRRL B-3471.

GenBank accession number (16S rRNA): AB023238, M23033, X95982.

\section{Enrichment and isolation}

Microaerophilic to anaerobic conditions are recommended, i.e. incubation in the presence of $\mathrm{N}_{2}, \mathrm{H}_{2}$ or $\mathrm{CO}_{2}$, or with anaerobic gasgenerating kits such as GasPak (Oxoid) or Anaerocult A (Merck). Different growth media may be used. Some of the more general growth media include MRS (De Man et al., 1960), Rogosa SLmedium (Rogosa et al., 1951), glucose-yeast extract (Whittenbury, 1965), acetate medium (Whittenbury, 1965), yeast extractglucose-citrate (YGC) broth (Garvie, 1967b), and HP Medium (Pearce \& Halligan, 1978). Tetrazolium-sucrose (TS) medium (Cavett et al., 1965), thallous-acetate-tetrazolium-sucrose (TTS) medium (Cavett et al., 1965), and HHD-medium (McDonald et al., 1987) have been used in the isolation of leuconostocs from plant material.

\section{THE GENUS PEDIOCOCCUS}

The name Pediococcus pertains to "a coccus growing in one plane". The genus contains eight species, viz. Pediococcus acidilactici, Pediococcus claussenii, Pediococcus cellicola, Pediococcus damnosus, Pediococcus inopinatus, Pediococcus parvulus, Pediococcus stilesii, Pediococcus pentosaceus (subspecies pentosaceus and intermedius), and the atypical species Pediococcus dextrinicus (Holzapfel et al., 2009b). The type species is $P$. damnosus.

Pediococci are Gram-positive, non-motile and spherical, but may be ovoid. The cells divide to form pairs (usually seen during early or mid-exponential growth) or divide in two perpendicular directions to form tetrads. Chain formation has not been recorded. Cells are small $(c a .0 .5-1.0 \mathrm{~mm})$, asporogenic, and catalase- and oxidase-negative. Some strains of $P$. pentosaceus 
TABLE 3

Major phenotypic characteristics differentiating members of the genus Leuconostoc from other genera of LAB (Björkroth \& Holzapfel, 2003, modified) ${ }^{\mathrm{a}}$.

\begin{tabular}{|c|c|c|c|c|c|c|c|}
\hline \multirow[b]{2}{*}{ Characteristic } & \multirow[b]{2}{*}{ Leuconostoc } & \multirow[b]{2}{*}{ Weissella } & \multirow{2}{*}{$\begin{array}{c}\text { Homofer- } \\
\text { mentative } \\
\text { ovoid-shaped } \\
\text { LAB } \\
\text { (Enterococcus, } \\
\text { Lactococcus, } \\
\text { Streptococcus) }\end{array}$} & \multicolumn{2}{|c|}{ Lactobacillus } & \multirow[b]{2}{*}{ Carnobacterium } & \multirow[b]{2}{*}{ Pediococcus } \\
\hline & & & & $\begin{array}{l}\text { Homo- } \\
\text { fermentative }\end{array}$ & $\begin{array}{c}\text { Hetero- } \\
\text { fermentative }\end{array}$ & & \\
\hline Morphology & $\begin{array}{l}\text { Ovoid to short } \\
\text { rods (pairs and } \\
\text { chains) }\end{array}$ & $\begin{array}{l}\text { Ovoid or rods } \\
\text { (pairs and chains) }\end{array}$ & $\begin{array}{l}\text { Ovoid (pairs and } \\
\text { chains) }\end{array}$ & rods & rods & rods & $\begin{array}{c}\text { round cocci } \\
\text { (tetrads and pairs) }\end{array}$ \\
\hline $\mathrm{CO}_{2}$ from glucose & + & + & - & - & + & $-(+)$ & - \\
\hline Hydrolysis of arginine & - & + or - & - or + & + or - & - or + & + & - or + \\
\hline Dextran from sucrose & $-/+$ & $-1+$ & - or + & - or + & - or + & - & - \\
\hline $\begin{array}{l}\text { Lactic acid isomer from } \\
\text { glucose }\end{array}$ & $\mathrm{D}(-)$ & $\mathrm{D}(-)$ or $\mathrm{DL}$ & $\mathrm{L}(+)$ & $\mathrm{D}(-), \mathrm{DL}$, or $\mathrm{L}(+)$ & DL & $\mathrm{L}(+)$ & $\mathrm{DL}$ or $\mathrm{L}(+)$ \\
\hline Peptidoglycan & LysAla/Ser ${ }^{b}$ & LysAla/Ser & Lys-Asp & $\begin{array}{l}\text { mainly Lys-Asp } \\
\text { and m-A2pm }\end{array}$ & $\begin{array}{l}\text { Lys-Asp and } \\
\text { others }^{\mathrm{d}}\end{array}$ & $m-A 2 p m$ & Lys-Asp \\
\hline
\end{tabular}

a Symbols: +, positive reaction; -, negative reaction; +/-, mostly positive; -/+, mostly negative.

bAbbreviations: Lys, lysine; Ala, alanine; Ser, serine; Asp, aspartate; m-A2pm, 2,6-diaminopimelic acid (2,6-diaminoheptanedioic acid).

'No Lys-Asp-types, but differentiations of Lys-Ala/Ser types, with the exception of $W$. kandleri.

${ }^{\mathrm{d}}$ Related to those of Leuconostoc and Weissella.

produce pseudocatalase (Simpson and Taguchi, 1995). Nitrate is not reduced. Arginine hydrolysis has only been reported for $P$. acidilactici and $P$. pentosaceus. Glucose is converted to lactic acid via the Embden-Meyerhof pathway. $\mathrm{CO}_{2}$ and ethanol are thus not produced. Growth has been recorded at $\mathrm{pH} 5$, but not at pH 9 (except for $P$. stilesii). Optimum growth temperature is 25$35^{\circ} \mathrm{C}$, but is species dependent. All species, except $P$. claussenii, produce DL-lactic acid from glucose.

Species group in a phylogenetically homogeneous cluster with $16 \mathrm{~S}$ rRNA sequence similarities greater than 94\%. The genus is thus well separated from other LAB (Fig. 1). Identification to species level is best obtained by $16 \mathrm{~S}$ rDNA gene sequencing (Collins et al., 1990; Kurzak et al., 1998; Omar et al., 2000; Barney et al., 2001), species-specific DNA probes (Lonvaud-Funel et al., 1993; Mora et al., 1997; 1998; Rodrigues et al., 1997), ribotyping (Jager \& Harlander, 1992; Satokari et al., 2000; Barney et al., 2001; Santos et al., 2005), randomly amplified polymorphic DNA (RAPD) PCR (Kurzak et al., 1998; Nigatu et al., 1998; Mora et al., 2000; Simpson et al., 2002; Fujii et al., 2005; Tamang et al., 2005), and pulsed-field gel electrophoresis (PFGE) ( Dellaglio et al., 1981; Luchansky et al., 1992; Barros et al., 2001). Simpson et al. (2006) developed a rapid PFGE protocol for species- and strain-level differentiation.

Sugar fermentations vary and genes encoding raffinose, melibiose, and sucrose metabolism by $P$. pentosaceus and some strains of $P$. acidilactici are plasmid-encoded (Gonzalez \& Kunka, 1986; Hoover et al., 1988). Key phenotypic characteristics that are used to differente pediococci are listed in Table 4. Since only $P$. damnosus, $P$. inopinatus, $P$. parvulus and $P$. pentosaceus are most frequently isolated from wine, descriptions of only these species are given. A detailed description of other species can be found in Holzapfel et al. (2009b).

\section{Pediococcus damnosus}

Growth is often slow and 2-3 days of incubation at $22^{\circ} \mathrm{C}$ may be required. Cysteine added to the medium improves growth. Growth on solid media is usually poor if not incubated anaerobically. Optimum growth is recorded at $\mathrm{pH}$ 5.5. Cells do not grow at $\mathrm{pH}$ 8.5. Growth temperature ranges from 8 to $30^{\circ} \mathrm{C}$. No growth occurs at $35^{\circ} \mathrm{C}$. Some strains grow in the presence of $4 \% \mathrm{NaCl}$, but none in the presence of $5.5 \% \mathrm{NaCl}$ (Simpson \& Taguchi, 1995). Acetoin or diacetyl are readily produced and causes a buttery odor. Exopolysaccharide formation has been reported for some strains (Carr, 1970). Pediococcus damnosus produces a 2-substituted (1-3)-beta-D-glucan (Duenas-Chasco et al., 1997). The inability to hydrolyze arginine separates $P$. damnosus from $P$. acidilactici and $P$. pentosaceus. Furthermore, $P$. damnosus has low genomic relatedness to $P$. acidilactici and $P$. pentosaceus (Dellaglio et al., 1981; Simpson \& Taguchi, 1995). In contrast, P. damnosus shows a high degree of genomic relatedness to $P$. inopinatus and P. parvulus (34-36\%) in DNA-DNA hybridization experiments. Such a close relationship is also reflected in the phylogenetic relatedness based on 16S rRNA sequences (Dobson et al., 2002).

Type strain: Be.1, ATCC 29358, CCUG 32251, CIP 102264, DSM 20331, JCM 5886, LMG 11484, NCIMB 12010, VKM B-1602.

GenBank accession number (16S rRNA): AJ318414, D87678.

\section{Pediococcus inopinatus}

Pediococcus inopinatus is phenotypically similar to $P$. parvulus, but distinguished by not fermenting pentoses and hydrolyzing 


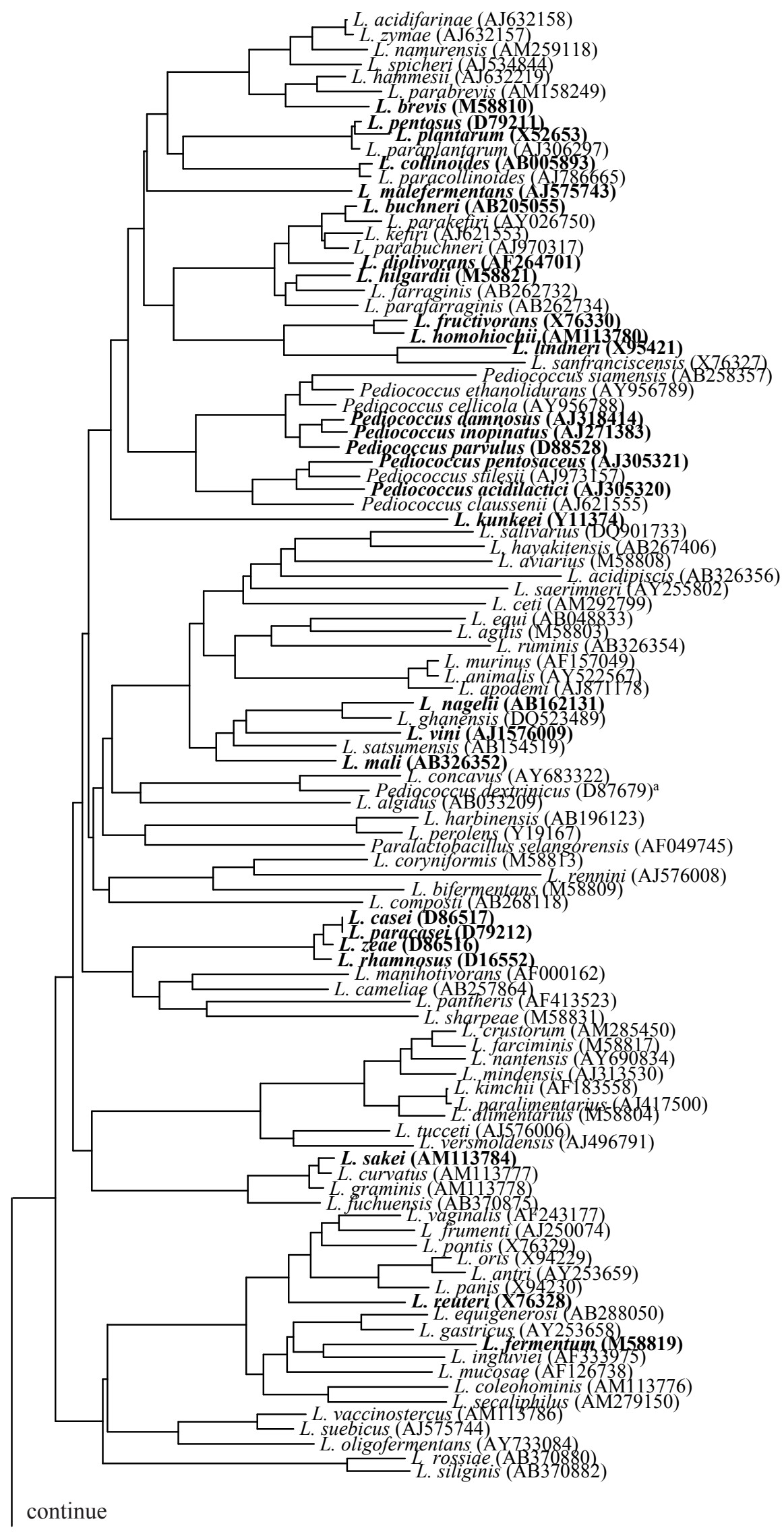

FIGURE 1

Phylogenetic relatedness of malolactic bacteria (printed in bold) with other lactic acid bacteria, as recorded by $16 \mathrm{~S}$ rRNA sequencing. ${ }^{\text {a }}$ Pediococcus dextrinicus has recently been reclassified as Lactobacillus dextrinicus (Haakensen et al., 2009). ${ }^{\mathrm{b}}$ Fructobacillus durionis, Fructobacillus ficulneus and Fructobacillus fructosus have previously been classified as Leuconostoc durionis, Leuconostoc ficulneum and Leuconostoc fructosum, respectively (Endo and Okada, 2008). The phylogenetic relatedness of only malolactic bacteria is shown in Fig. 2 . 


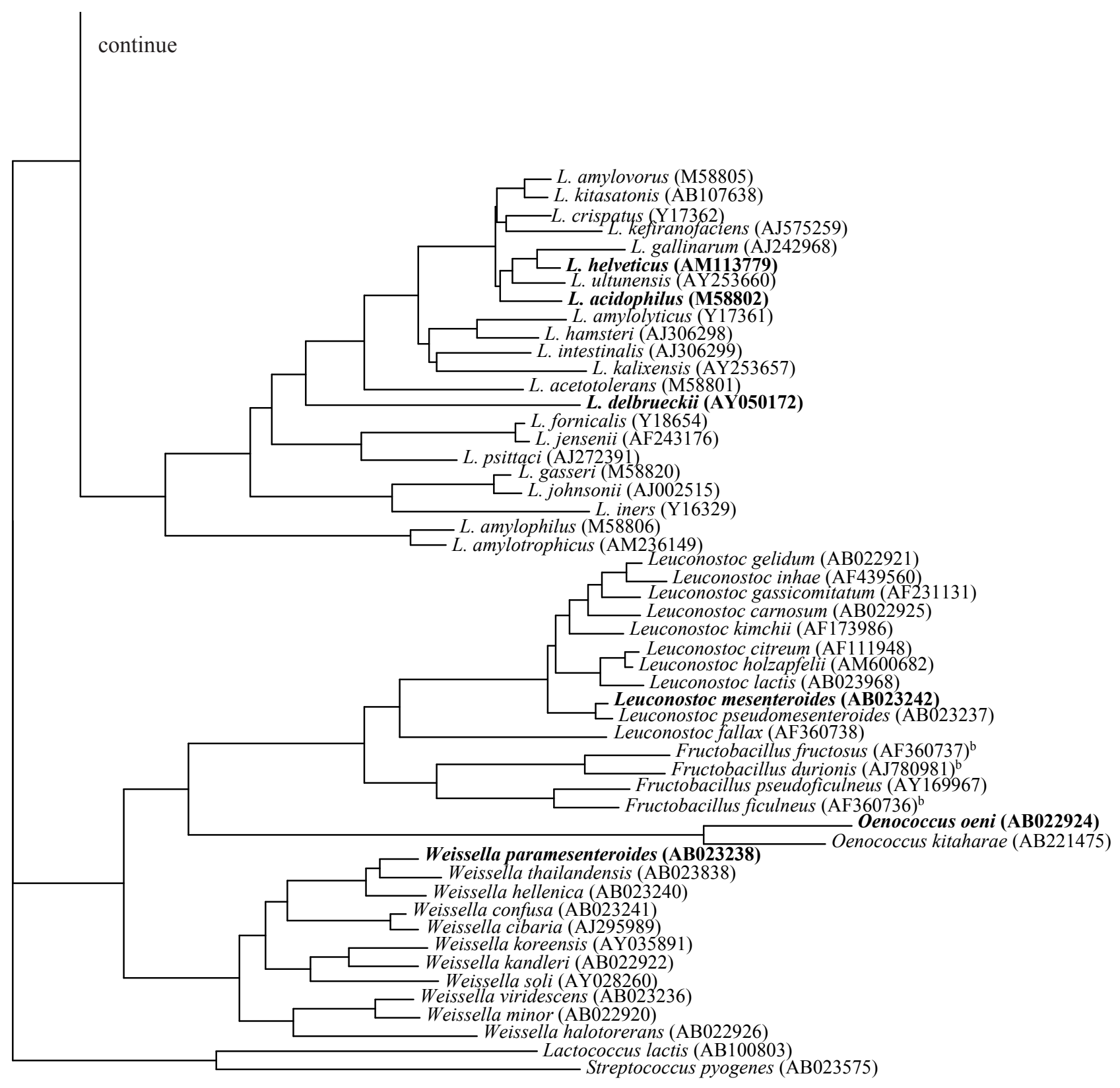

FIGURE 1 (continued) 
TABLE 4

Phenotypic characteristics differentiating Pediococcus spp. ${ }^{\mathrm{a}, \mathrm{b}}$

\begin{tabular}{|c|c|c|c|c|c|c|c|c|c|}
\hline Characteristic & $\begin{array}{c}\text { P. dam- } \\
\text { nosus }\end{array}$ & $\begin{array}{c}\text { P. acidi- } \\
\text { lactici }\end{array}$ & $\begin{array}{c}\text { P. celli- } \\
\text { cola }\end{array}$ & $\begin{array}{c}\text { P. claus- } \\
\text { senii }\end{array}$ & $\begin{array}{l}\text { P. dextri- } \\
\text { nicus }\end{array}$ & $\begin{array}{c}P . \text { inopi- } \\
\text { natus }\end{array}$ & $\begin{array}{c}\text { P. par- } \\
\text { vulus }\end{array}$ & $\begin{array}{c}\text { P. pento- } \\
\text { saceus }\end{array}$ & P. stilesii \\
\hline \multicolumn{10}{|l|}{ Growth at } \\
\hline $\mathrm{pH} 4.5$ & + & + & + & + & - & + & + & + & $+^{\mathrm{c}}$ \\
\hline pH 7.0 & - & + & + & $+\mathrm{c}$ & + & $\mathrm{d}$ & $\mathrm{d}$ & + & $+^{\mathrm{c}}$ \\
\hline pH 8.0 & - & + & + & $+^{c}$ & + & - & - & + & $+^{c}$ \\
\hline pH 9.0 & - & - & - & - & - & - & - & - & $+^{\mathrm{c}}$ \\
\hline $35 \mathrm{C}$ & - & + & + & + & + & + & + & + & $+^{\mathrm{c}}$ \\
\hline $40 \mathrm{C}$ & - & + & + & $+^{c}$ & + & $\mathrm{d}$ & - & $\mathrm{d}$ & $+^{c}$ \\
\hline $45 \mathrm{C}$ & - & + & - & - & - & - & - & $\mathrm{d}$ & $+^{\mathrm{c}}$ \\
\hline $48 \mathrm{C}$ & - & + & - & - & - & - & - & - & $-{ }^{c}$ \\
\hline Lactic acid configuration & DL & DL & DL & $\mathrm{L}(+)^{\mathrm{c}}$ & $\mathrm{L}(+)$ & DL & DL & DL & DL \\
\hline \multicolumn{10}{|l|}{ Acid from } \\
\hline Arabinose & - & $\mathrm{d}$ & $\mathrm{d}$ & - & - & - & - & + & $-^{\mathrm{c}}$ \\
\hline Galactose & + & + & + & - & $\mathrm{d}$ & + & $\mathrm{d}$ & + & $+^{c}$ \\
\hline Lactose & - & $\mathrm{d}$ & + & - & $\mathrm{d}$ & + & - & + & $-{ }^{c}$ \\
\hline Maltose & $\mathrm{d}$ & - & + & $\mathrm{d}$ & + & + & $\mathrm{d}$ & + & $+^{\mathrm{c}}$ \\
\hline Melizitose & $\mathrm{d}$ & - & - & - & - & - & - & - & $-^{c}$ \\
\hline Ribose & - & + & + & + & - & - & - & + & $+^{c}$ \\
\hline Xylose & - & + & + & - & - & - & - & $\mathrm{d}$ & $-^{\mathrm{c}}$ \\
\hline Max. $\mathrm{NaCl}$ conc. for growth & 5 & 10 & $?$ & 5 & 6 & 8 & 8 & 10 & $8^{c}$ \\
\hline
\end{tabular}

asymbols:,$+ 90 \%$ or more strains positive;,$- 90 \%$ or more strains negative; d, 11-89\% of strains positive.

'Data partially adapted from Simpson \& Taguchi (1995), Franz et al. (2006), Holzapfel et al. (2005), and Zhang et al. (2005).

'Data have only been obtained with the type strain of P. claussenii and P. stilesii.

arginine. Cells grow optimally between 30 and $32^{\circ} \mathrm{C}$ and withstand 6-8\% (w/v) NaCl. Some strains form polysaccharides. Pediococcus inopinatus is best separated from $P$. parvulus by electrophoresis of $\mathrm{L}-(+)-$ and D-(-)-LDH's, DNA-DNA hybridization and comparison of $16 \mathrm{~S}$ rRNA sequences.

Type strain: ATCC 49902, CCUG 38496, CIP 102406, DSM 20285, JCM 12518, LMG 11409, NCIMB 12564.

GenBank accession number (16S rRNA): AJ271383.

\section{Pediococcus parvulus}

Best growth has been recorded in broth supplemented with L-cysteine and Tween-80. Larger colonies develop when cells are streaked onto tomato juice agar and incubated anaerobically at $30^{\circ} \mathrm{C}$ for $48 \mathrm{~h}$. Some strains require asparagine, but not folic acid. Optimal growth is recorded in medium with an initial $\mathrm{pH}$ of 6.5. Growth occurs in the presence of $5.5-8.0 \%(\mathrm{w} / \mathrm{v}) \mathrm{NaCl}$. Pentoses are not fermented. Some strains produce exopolysaccharides and high levels of histamine in wine.

Type strain: ATCC 19371, CCUG 28439, CIP 102262, DSM 20332, JCM 5889, LMG 11486, NBRC 100673, NCIMB 9447, VKM B-1604.

GenBank accession number (16S rRNA): D88528.

\section{Pediococcus pentosaceus}

Cells grow equally well aerobically and anaerobically in MRS at $30^{\circ} \mathrm{C}$. Litmus milk reactions are variable and may be related to growth requirements. The requirement for folic acid varies between strains. Optimal growth $\mathrm{pH}$ is between 6.0 and 6.5, but growth may occur at $\mathrm{pH}$ 8.0. Cells grow in the presence of $9-10 \%$ (w/v) NaCl. The ability to ferment maltose differentiates $P$. pentosaceus from $P$. acidilactici (although not invariably). Cells may be weakly catalase-positive when grown in medium with low glucose content.

Type strain: ATCC 33316, CCUG 32205, CIP 102260, DSM 20336, JCM 5890, LMG 11488, NCIMB 12012, NCTC 12956.

GenBank accession number (16S rRNA): AJ305321, M58834.

\section{Enrichment and isolation}

Pediococcus spp. share several physiological properties with Lactobacillus, Leuconostoc and Weissella spp. Most culture media are thus not selective. SL Medium (Rogosa et al., 1951) and Acetate Agar (Whittenbury, 1965) are semi-selective. Pediococcus Selective Medium (PSM), which is a modification of MRS medium (De Man et al., 1961), supplemented with cysteine hydrochloride, novobiocin, vancomycin, and nystatin, may also be used. Growth is usually stimulated under anaerobic conditions.

Several growth media have been developed to detect spoilage strains of $P$. damnosus and $P$. claussenii in beer. MRS agar adjusted to $\mathrm{pH} 5.5$ and MRS broth supplemented with beer $(1: 1 \mathrm{v} / \mathrm{v})$ proved semi selective, but only when incubated at $22^{\circ} \mathrm{C}$ in the presence of $90 \% \mathrm{~N}_{2}+10 \% \mathrm{CO}_{2}$. Kirin-Ohkochi-Taguchi (KOT) medium, consisting of beer, malt extract, liver concentrate, maltose, L-malic 
acid, cytidine, thymidine, actidione and sodium azide, may also be used (Taguchi et al., 1990). As far as we know, the medium has not been used to isolate pediococci from wine.

\section{THE GENUS LACTOBACILLUS}

The name Lactobacillus pertains to a small rod isolated from milk. Cells are Gram-positive, catalase negative rods, usually non-motile, long and slender (often bent), or short coryneform-like coccobacilli (Garvie, 1986). Pseudocatalase may be produced by some strains, but only in the presence of heme. Cells occur single, but more than often in chains of varying lengths. Endospores are not produced. Some strains have internal granulations or bipolar cellular inclusions, visible when Gram-stained or stained with methylene blue. Metabolism is fermentative and obligately saccharoclastic. At least half of the end product is lactate. Additional products may include acetate, ethanol, $\mathrm{CO}_{2}$, formate, or succinate. Lactate is usually not fermented. Growth is facultatively anaerobic, with best surface growth recorded when plates are incubated in the presence of 5 to $10 \% \mathrm{CO}_{2}$. Nitrate reduction is unusual and only detected when the terminal $\mathrm{pH}$ is above 6.0 and/or heme is added to the growth medium. Gelatin is not liquefied and casein is not digested. Indole and $\mathrm{H}_{2} \mathrm{~S}$ are not produced. All species require complex growth media with amino acids, peptides, nucleic acid derivatives, vitamins, salts, fatty acids or fatty acid esters, and fermentable carbohydrates. Growth temperature ranges from 2 to $53^{\circ} \mathrm{C}$, with the optimum between 30 and $40^{\circ} \mathrm{C}$. All species are aciduric, with optimal growth between $\mathrm{pH} 5.5$ and 6.2. Species have been isolated from various niches, including grape must, wine, beer, dairy products, grain products, meat and fish, fruit, pickled vegetables, sauerkraut, silage, sourdough, water, soil and sewage. Many of the species are part of the normal flora in the mouth, intestinal tract, and vagina of humans and animals. Pathogenicity is absent or, in rare cases, restricted to individuals with an underlying disease or immune deficiency.

This genus is the largest amongst all LAB. In the 1986 edition of Bergey's Manual of Systematic Bacteriology (Sneath et al., 1986), 44 Lactobacillus species were listed. Since then, the number of validly published species escalated to approximately 100 , with at least 16 subspecies.

Although many Lactobacillus spp. have the ability to convert L-malate to L-lactate and $\mathrm{CO}_{2}$, only a few survive alcoholic fermentation. The most prominent species are Lactobacillus brevis, Lactobacillus plantarum, Lactobacillus collinoides, Lactobacillus buchneri, Lactobacillus hilgardii, Lactobacillus fructivorans, Lactobacillus kunkeei, Lactobacillus nagelii, Lactobacillus vini, Lactobacillus mali and Lactobacillus fermentum. At the end of alcoholic fermentation, growth commences and cell numbers may increase to $10^{7}$ cells/mL (König \& Fröhlich, 2009).

Lactobacillus spp. less frequently isolated from wine are Lactobacillus pentosus, Lactobacillus malefermentans, Lactobacillus homohiochii, Lactobacillus casei, Lactobacillus paracasei, Lactobacillus zeae, Lactobacillus rhamnosus, Lactobacillus sakei, Lactobacillus reuteri, Lactobacillus helveticus, Lactobacillus acidophilus and Lactobacillus delbrueckii. Lactobacillus lindneri has recently been isolated from Australian wines (Bae et al., 2006).

Lactobacillus delbrueckii is separated into four subspecies, e.g. delbrueckii, bulgaricus, lactis and indicus. Differentiation between these subspecies is by only a few sugar fermentations. Subspecies delbrueckii cannot ferment lactose. Subspecies bulgaricus and subspecies indicus cannot ferment maltose. Subspecies bulgaricus cannot ferment sucrose, whereas trehalose is only fermented by subspecies lactis.

Lactobacillus paracasei is separated into subspecies paracasei and subspecies tolerans. Subspecies tolerans is distinguished from subspecies paracasei by being unable to ferment amygdalin, cellobiose, esculin, mannitol, melezitose, ribose and sucrose.

Lactobacillus plantarum subsp. argentoratensis is difficult to distinguish from L. plantarum subsp. plantarum and is only differentiated by a single sugar fermentation (subspecies argentoratensis cannot ferment melezitose). Further differentiation of these two subspecies from the phenotypically similar species Lactobacillus paraplantarum and Lactobacillus pentosus is only possible with genotypic methods (Bringel et al., 2005).

The two subspecies of L. sakei (subsp. sakei and subsp. carnosus) is phenotypically closely related and only reliably differentiated by numerical analysis of total soluble cell protein patterns and RAPD-PCR.

The phylogenetic relationship of wine Lactobacillus spp. with other LAB is shown in Fig. 1. In some cases, species can be differentiated based on simple phenotypic characteristics (Table 5). Differentiation based on sugar fermentation profiles has to be evaluated with care, since many of the genes encoding sugar fermentations are located on plasmids. Identification of species has to be verified by evaluation of genotypic properties. For detailed description of Lactobacillus spp. readers are referred to Hammes \& Hertel (2009).

\section{Key tests to differentiate malolactic bacteria}

The phylogenetic relatedness of malolactic bacteria is shown in Fig. 2. Key characteristics used to differentiate amongst MLB of the genera Oenococcus, Leuconostoc, Pediococcus and Lactobacillus is summarized in Fig. 3. The type strains of species found in wine are listed below. 16S rDNA gene sequence accession numbers of the species is indicated in Fig. 1.

Lactobacillus acidophilus: ATCC 4356, CCUG 5917, CIP 76.13, DSM 20079, NBRC 13951, JCM 1132, LMG 9433, LMG 13550, NCTC 12980, NRRL B-4495, VKM B-1660.

Lactobacillus brevis: ATCC 14869, CCUG 30670, CIP 102806, DSM 20054, JCM 1059, LMG 6906, LMG 7944, NRRL B-4527.

Lactobacillus buchneri: ATCC 4005, CCUG 21532, CIP 103023, DSM 20057, JCM 1115, LMG 6892, NCAIM B.01145, NRRL B-1837, VKM B-1599.

Lactobacillus casei: ATCC 393, BCRC 10697, CCUG 21451, CECT 475, CIP 103137, DSM 20011, IAM 12473, NBRC 15883, JCM 1134, KCTC 3109, LMG 6904, NCIMB 11970, NCIMB 11970, NRRL B-1922.

Lactobacillus collinoides: ATCC 27612, CCUG 32259, CIP 103008, DSM 20515, JCM 1123, LMG 9194.

Lactobacillus delbrueckii subsp. delbrueckii: ATCC 9649, CCUG 34222, CIP 57.8, DSM 20074, NBRC 3202, JCM 1012, LMG 6412, NCIMB 8130, NRRL B-763, VKM B-1596. 
TABLE 5

Key characteristics of Lactobacillus species ${ }^{\mathrm{a}}$

\begin{tabular}{|c|c|c|c|c|c|c|c|c|}
\hline & & $\begin{array}{c}\text { L. delbrueckii } \\
\text { subsp. } \\
\text { delbrueckii }\end{array}$ & $\begin{array}{c}\text { L. acido- } \\
\text { philus }\end{array}$ & $\begin{array}{l}\text { L. helve- } \\
\text { ticus }\end{array}$ & L. mali & L. nagelii & L. casei & $\begin{array}{c}\text { L. homo- } \\
\text { hiochii }\end{array}$ \\
\hline Fermentation type & & $\mathrm{A}^{\mathrm{b}}$ & $\bar{A}$ & A & $\mathrm{A}$ & A & $\mathrm{B}^{\mathrm{d}}$ & B \\
\hline Peptidoglycan type & & Lys-D-Asp & Lys-D-Asp & Lys-D-Asp & $\mathrm{mDpm}^{\mathrm{c}}$ & $\mathrm{mDpm}$ & Lys-D-Asp & Lys-D-Asp \\
\hline $\mathrm{G}+\mathrm{C}$ content $(\mathrm{mol} \%)$ & & $49-51$ & $34-37$ & 37 & 32.5 & ND & $45-47$ & $35-38$ \\
\hline Lactic acid configuration & & $\mathrm{D}$ & DL & DL & $\mathrm{L}$ & $\mathrm{DL}$ & $\mathrm{L}$ & DL \\
\hline Growth at $15 \mathrm{C} / 45 \mathrm{C}$ & & $-/+$ & $-/+$ & $-/+$ & $+/ \mathrm{d}$ & $+/+$ & $+/-$ & $+/-$ \\
\hline Gas from glucose & & - & - & - & - & - & - & - \\
\hline \multicolumn{9}{|l|}{ Fermentation of: } \\
\hline Amygdalin & & - & + & - & + & + & + & - \\
\hline Cellobiose & & - & + & - & $\mathrm{d}$ & + & + & $\mathrm{d}$ \\
\hline Mannitol & & + & + & $\mathrm{d}$ & + & + & + & $\mathrm{d}$ \\
\hline Melibiose & & - & $\mathrm{d}$ & - & $\mathrm{d}$ & - & - & - \\
\hline Raffinose & & - & $\mathrm{d}$ & - & $\mathrm{d}$ & - & - & - \\
\hline \multirow[t]{2}{*}{ Sucrose } & & + & + & - & + & + & + & - \\
\hline & L. jensenii & $\begin{array}{l}\text { L. paracasei } \\
\text { subsp. } \\
\text { paracasei }\end{array}$ & L. pentosus & $\begin{array}{l}\text { L. plantarum } \\
\text { subsp. } \\
\text { plantarum }\end{array}$ & L. rhamnosus & L. sakei & L. vini & L. zeae \\
\hline Fermentation type & B & B & $\mathrm{B}$ & $\mathrm{B}$ & $\mathrm{B}$ & $\mathrm{B}$ & $\mathrm{B}$ & $\mathrm{B}$ \\
\hline Peptidoglycan type & Lys-D-Asp & Lys-D-Asp & $\mathrm{mDpm}$ & $\mathrm{mDpm}$ & Lys-D-Asp & Lys-D-Asp & $\mathrm{mDpm}$ & Lys-D-Asp \\
\hline $\mathrm{G}+\mathrm{C}$ content $(\mathrm{mol} \%)$ & $33-35$ & $45-47$ & $46-47$ & $44-46$ & $45-47$ & $42-44$ & 39 & $48-49$ \\
\hline Lactic acid isomer(s) & $\mathrm{D}$ & $\mathrm{L}$ & DL & DL & $\mathrm{L}$ & $\mathrm{DL} / \mathrm{L}(\mathrm{D})$ & DL & $\mathrm{L}(\mathrm{D})$ \\
\hline Growth at $15 \mathrm{C} / 45 \mathrm{C}$ & $-/+$ & $+/ \mathrm{d}$ & $+/-$ & $+/-$ & $+/+$ & $+/-$ & $-/+$ & $+/+$ \\
\hline Gas from glucose & - & - & - & - & - & - & - & - \\
\hline \multicolumn{9}{|l|}{ Carbohydrate fermentation } \\
\hline Amygdalin & + & + & + & + & + & - & + & + \\
\hline Cellobiose & + & + & + & + & + & $\mathrm{d}$ & + & + \\
\hline Mannitol & $\mathrm{d}$ & + & + & + & + & - & - & + \\
\hline Melibiose & - & - & + & + & - & + & - & - \\
\hline Raffinose & - & - & + & + & - & - & - & - \\
\hline \multirow[t]{2}{*}{ Sucrose } & + & + & + & + & + & + & + & + \\
\hline & & L. brevis & L. buchneri & L. collinoides & L. fermentum & L. fructivorans & L. hilgardii & L. kunkeei \\
\hline Peptidoglycan type & & Lys-D-Asp & Lys-D-Asp & Lys-D-Asp & Orn-D-Asp & Lys-D-Asp & Lys-D-Asp & Lys-D-Asp \\
\hline $\mathrm{G}+\mathrm{C}$ content $(\mathrm{mol} \%)$ & & $44-47$ & $44-46$ & 46 & $52-54$ & $38-40$ & $39-41$ & ND. \\
\hline Growth at $15 \mathrm{C} / 45 \mathrm{C}$ & & $+/-$ & $+/-$ & $+/-$ & $-/+$ & $+/-$ & $+/-$ & $+/-$ \\
\hline $\mathrm{NH} 3$ from arginine & & + & + & + & + & + & + & - \\
\hline Gas from glucose & & + & + & + & + & + & + & + \\
\hline \multicolumn{9}{|l|}{ Carbohydrate fermentation } \\
\hline Arabinose & & + & + & + & $\mathrm{d}$ & - & - & ND \\
\hline Cellobiose & & - & - & - & $\mathrm{d}$ & - & - & - \\
\hline Esculin & & d & $\mathrm{d}$ & + & - & - & - & - \\
\hline Galactose & & $\mathrm{d}$ & $\mathrm{d}$ & + & + & - & d & - \\
\hline Maltose & & + & + & + & + & $\mathrm{d}$ & + & - \\
\hline Mannose & & - & - & - & $\mathrm{w}$ & - & - & - \\
\hline Melezitose & & - & + & + & - & - & $\mathrm{d}$ & - \\
\hline Melibiose & & + & + & + & + & - & - & - \\
\hline Raffinose & & d & d & - & + & - & - & w \\
\hline Ribose & & + & + & + & + & $\mathrm{w}$ & + & - \\
\hline Sucrose & & $\mathrm{d}$ & $\mathrm{d}$ & - & + & d & $\mathrm{d}$ & + \\
\hline Trehalose & & - & - & - & $\mathrm{d}$ & - & - & - \\
\hline xylose & & $\mathrm{d}$ & $\mathrm{d}$ & + & $\mathrm{d}$ & - & + & - \\
\hline
\end{tabular}

${ }^{\mathrm{a}}$ Data obtained from Hammes \& Hertel (2009)

${ }^{\mathrm{b}} \mathrm{A}$ : Obligately homofermentative

${ }^{\mathrm{c}} \mathrm{mDpm}=$ meso-diaminopimelic acid

${ }^{\mathrm{d} B}$ : Facultatively heterofermentative 
TABLE 5 (continued)

Key characteristics of Lactobacillus species ${ }^{\text {a }}$

\begin{tabular}{lccc}
\hline & $\begin{array}{c}\text { L. } \\
\text { lindneri }\end{array}$ & $\begin{array}{c}\text { L. } \\
\text { malefermentans }\end{array}$ & $\begin{array}{c}\text { L. } \\
\text { reuteri }\end{array}$ \\
\hline Peptidoglycan type & Lys-D-Asp & Lys-D-Asp & Lys-D-Asp \\
G + C content (mol\%) & 35 & $41-42$ & $40-42$ \\
Growth at 15 C/45 C & $+/-$ & $+/-$ & $-/+$ \\
NH3 from arginine & - & + & + \\
Gas from glucose & + & + & + \\
Carbohydrate fermentation & & - & + \\
Arabinose & - & - & - \\
Cellobiose & - & - & + \\
Esculin & - & - & + \\
Galactose & - & - & - \\
Maltose & + & - & + \\
Mannose & - & - & + \\
Melezitose & - & - & + \\
Melibiose & - & - & - \\
Raffinose & - & - & - \\
Ribose & - & - & + \\
Sucrose & - & - & + \\
Trehalose & - & - & + \\
Xylose & - & - & + \\
\hline Obligaty & - & - & + \\
\hline
\end{tabular}

abligately heterofermentative lactobacilli

Lactobacillus delbrueckii subsp. bulgaricus: ATCC 11842, CCUG 41390, CIP 101027, DSM 20081, NBRC 13953, JCM 1002, LMG 6901, LMG 13551, NCTC 12712, VKM B-1923.

Lactobacillus delbrueckii subsp. lactis: ATCC 12315, CCUG 31454, CIP 101028, DSM 20072, JCM 1248, LMG 7942, NRRL B-4525.

Lactobacillus delbrueckii subsp. indicus: NCC725, DSM 15996, LMG 22083.

Lactobacillus fermentum: ATCC 14931, CCUG 30138, CIP 102980, DSM 20052, NBRC 15885, JCM 1173, LMG 6902, NCCB 46038, NCIMB 11840, NRRL B-4524.

Lactobacillus fructivorans: ATCC 8288, CCUG 32260, CIP 103042, DSM 20203, NBRC 13954, JCM 1117, LMG 9201, NRRL B-1841.

Lactobacillus helveticus: ATCC 15009, CCUG 30139, CIP 103146, DSM 20075, NBRC 15019, JCM 1120, LMG 6413, LMG 13555, NRRL B-4526.

Lactobacillus hilgardii: ATCC 8290, CCUG 30140, CIP 103007 , DSM 20176, NBRC 15886, JCM 1155, LMG 6895, NRRL B-1843.

Lactobacillus homohiochii: ATCC 15434, CCUG 32247, CIP 103141, DSM 20571, NBRC 15887, JCM 1199, JCM 7793, LMG 9478, NRRL B-4559.

Lactobacillus kunkeei: YH-15, ATCC 700308, DSM 12361.

Lactobacillus lindneri: KACC 12445, CIP 102983, DSM 20690, JCM 11027, LMG 14528.

Lactobacillus malefermentans: D2 MF1, ATCC 49373, CCUG 32206, CIP 103367, DSM 5705, NBRC 15905, JCM 12497 , LMG 11455, NCIMB 701410.
Lactobacillus mali: ATCC 27053, CCUG 30141, CCUG 32228, CIP 103142, DSM 20444, JCM 1116, LMG 6899, NCIMB 10560, NRRL B-4563, VKM B-1600.

Lactobacillus nagelii: LuE10, ATCC 700692, CCUG 43575, DSM 13675, JCM 12492.

Lactobacillus paracasei subsp. paracasei: ATCC 25302, CCUG 32212, CIP 103918, DSM 5622, NBRC 15889, JCM 8130, LMG 13087, NCIMB 700151.

Lactobacillus paracasei subsp. tolerans: ATCC 25599, CCUG 34829, CIP 102994, CIP 103024, DSM 20258, NBRC 15906, JCM 1171, LMG 9191, NCIMB 9709.

Lactobacillus pentosus: ATCC 8041, CCUG 33455, CIP 103156 , DSM 20314, JCM 1558, LMG 10755, NCAIM B.01727, NCCB 32014, NCIMB 8026, NRRL B-227, NRRL B-473.

Lactobacillus plantarum subsp. plantarum: ATCC 14917, CCUG 30503, CIP 103151, DSM 20174, NBRC 15891, JCM 1149, LMG 6907, NCIMB 11974, NRRL B-4496.

Lactobacillus plantarum subsp. argentoratensis: DKO 22, CIP 108320, DSM 16365.

Lactobacillus reuteri: ATCC 23272, CCUG 33624, CIP 101887 , DSM 20016, NBRC 15892, JCM 1112, LMG 9213, LMG 13557, NRRL B-14171.

Lactobacillus rhamnosus: ATCC 7469, CCUG 21452, CIP A157, DSM 20021, NBRC 3425, JCM 1136, LMG 6400, NCAIM B.01147, NCCB 46033, NCIMB 6375, NCTC 12953, NRRL B-442, VKM B-574.

Lactobacillus sakei subsp. sakei: ATCC 15521, CCUG 30501, CIP 103139, DSM 20017, NBRC 15893, JCM 1157, LMG 9468, LMG 13558. 


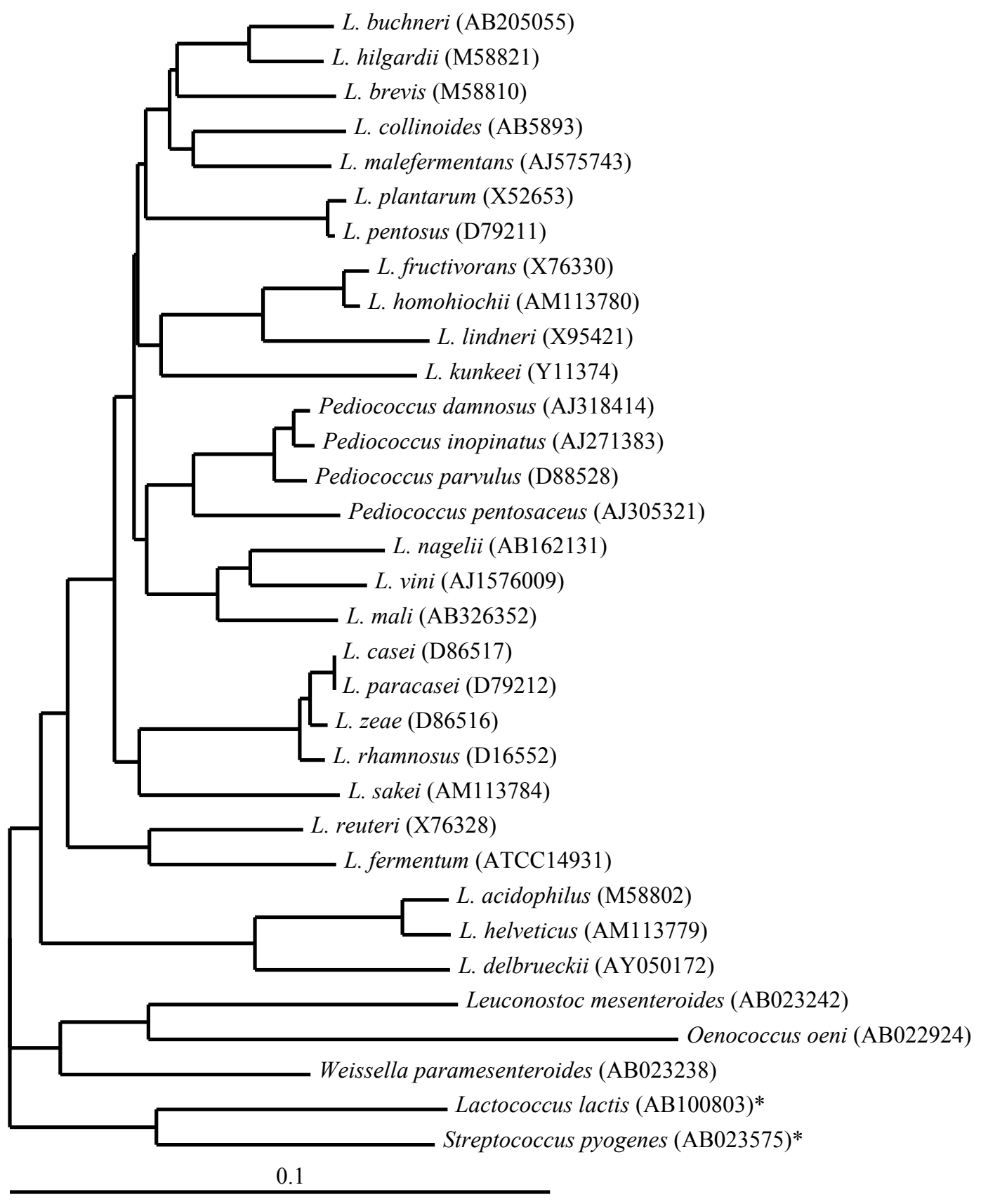

FIGURE 2

Phylogenetic relatedness of malolactic LAB without other LAB, as recorded by $16 \mathrm{~S}$ rRNA sequencing. Lactococcus lactis and Streptococcus pyogenes were kept as outside reference strains (as also in Fig. 1). 


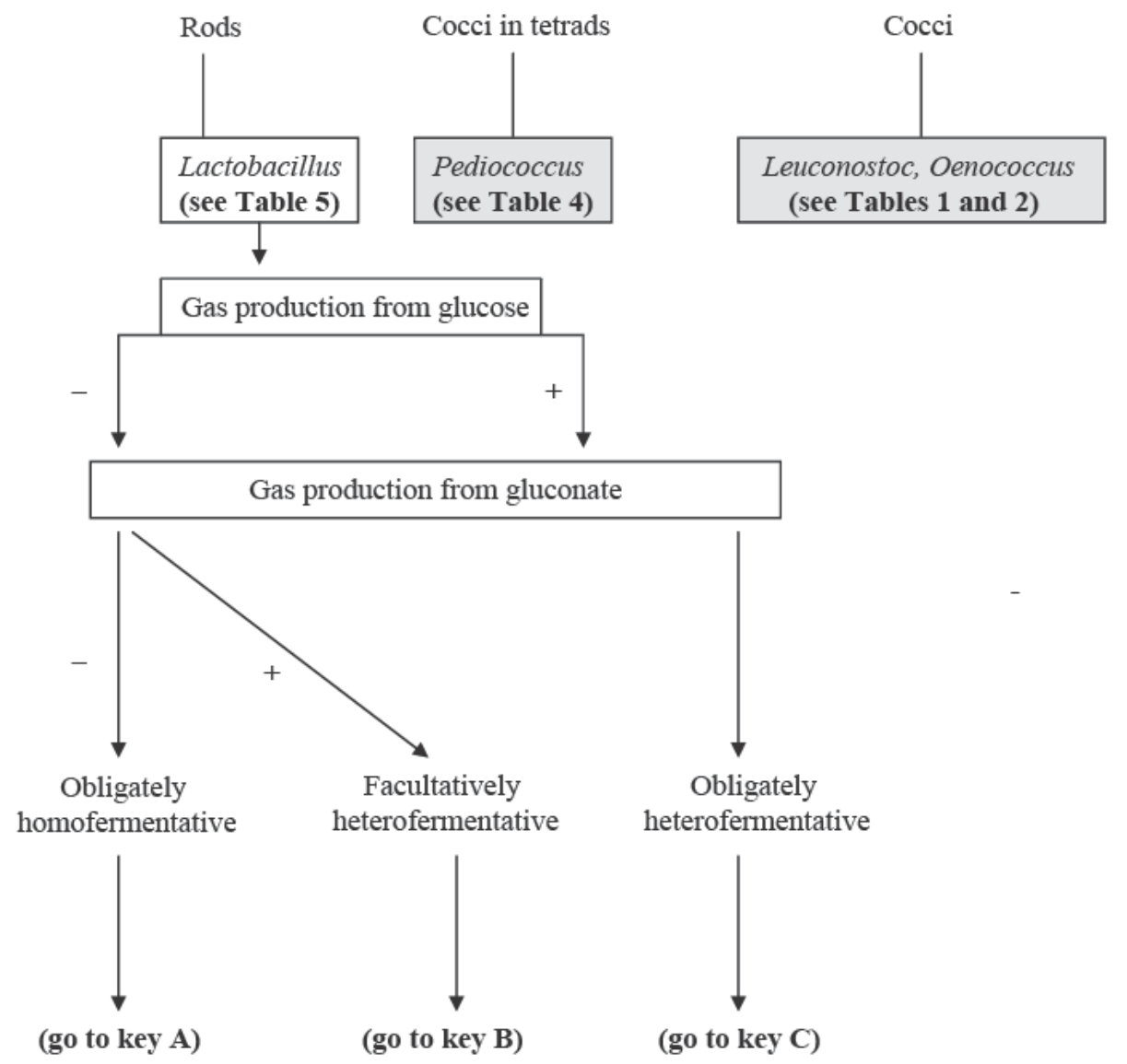

Key A Obligately homofermentative lactobacilli

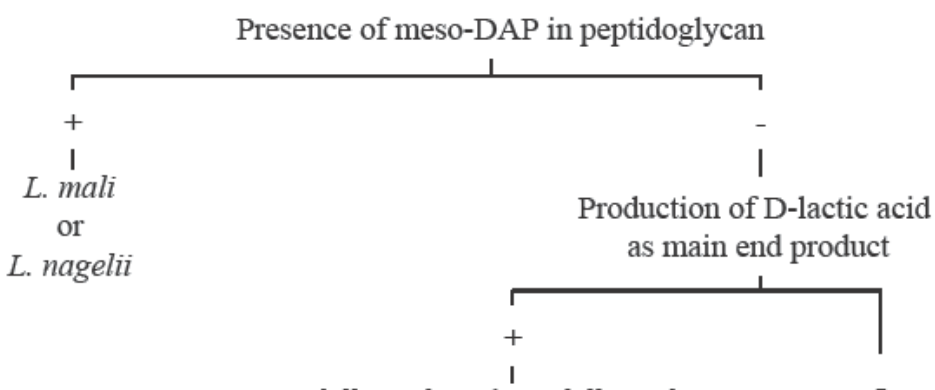

L. delbrueckii subsp. delbrueckii

Fermentation of amygdalin, cellobiose and sucrose

L. acidophilus

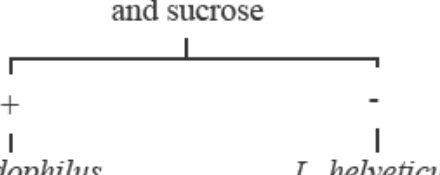

FIGURE 3

Key phenotypic characteristics to differentiate malolactic bacteria. 


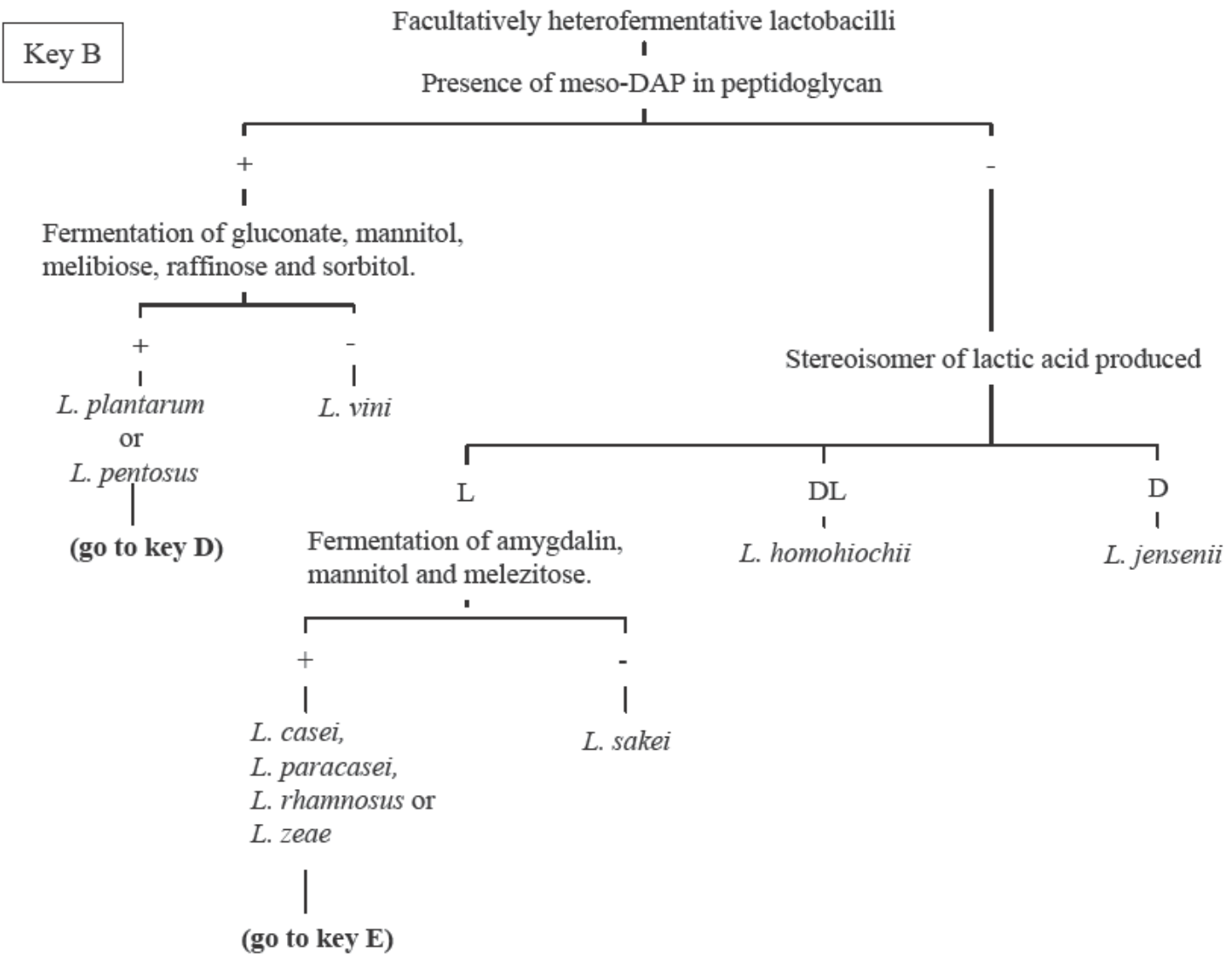

Key C Obligately heterofermentative lactobacilli

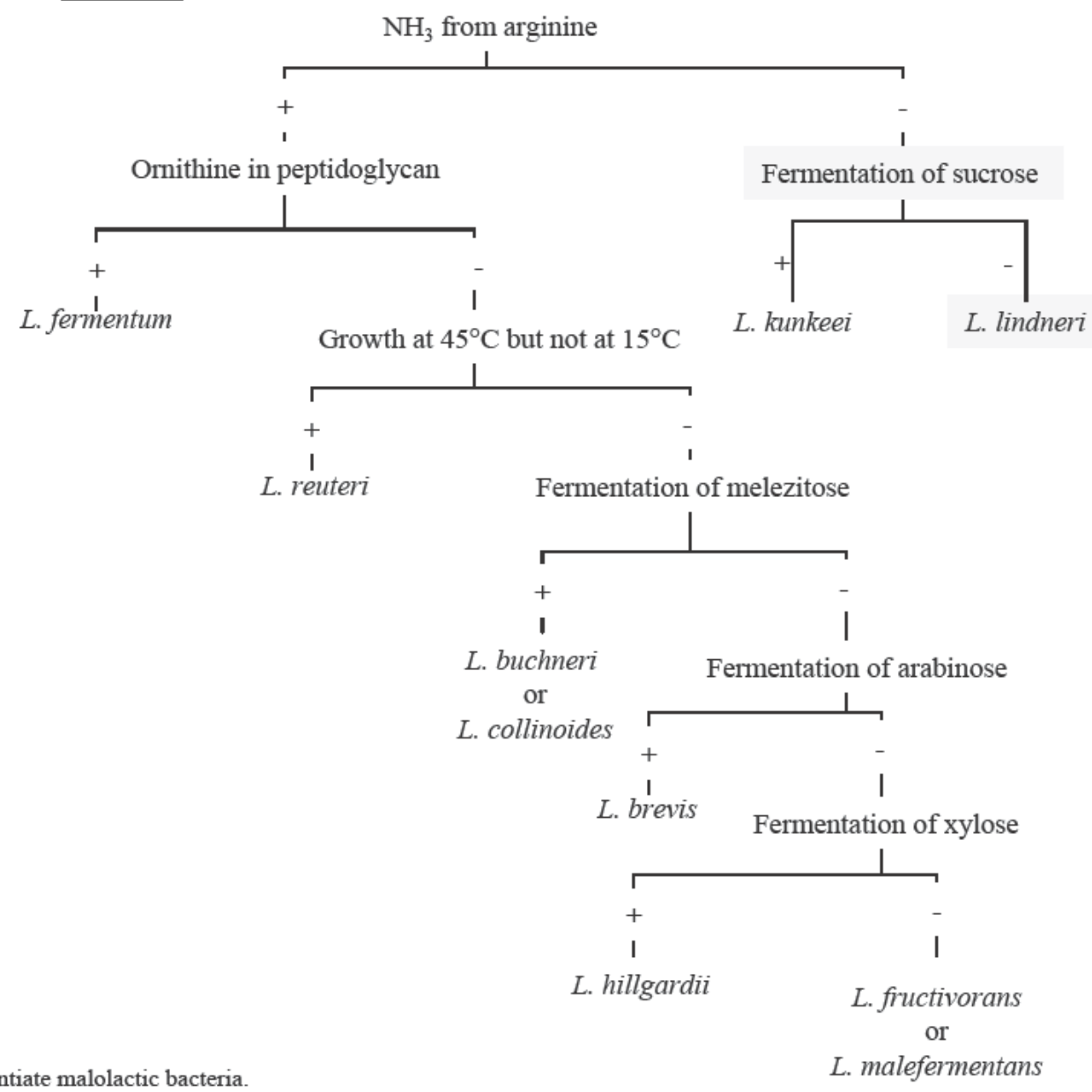

FIGURE 3 (continued)

L. malefermentans 
Key D

Species-specific DNA primers for multiplex PCR assay of $L$. plantarum subsp. plantarum, L. plantarum subsp. argentoratensis, L. pentosus, and L. paraplantarum

\begin{tabular}{ll}
\hline Primer & Sequence (5' to 3') \\
\hline paraF & GTCACAGGCATTACGAAAAC \\
pentF & CAGTGGCGCGGTTGATATC \\
planF & CCGTTTATGCGGAACACCTA \\
pREV & TCGGGATTACCAAACATCAC \\
\hline
\end{tabular}

L. plantarum subsp. plantarum produces a 318 bp amplicon, L. plantarum subsp. argentoratensis a $318 \mathrm{bp}$ amplicon and a 120 bp amplicon, L. pentosus a $218 \mathrm{bp}$ amplicon, and L. paraplantarum a $107 \mathrm{bp}$ amplicon, as indicated below (from Torriani et al., 2001 and Bringel et al., 2005).

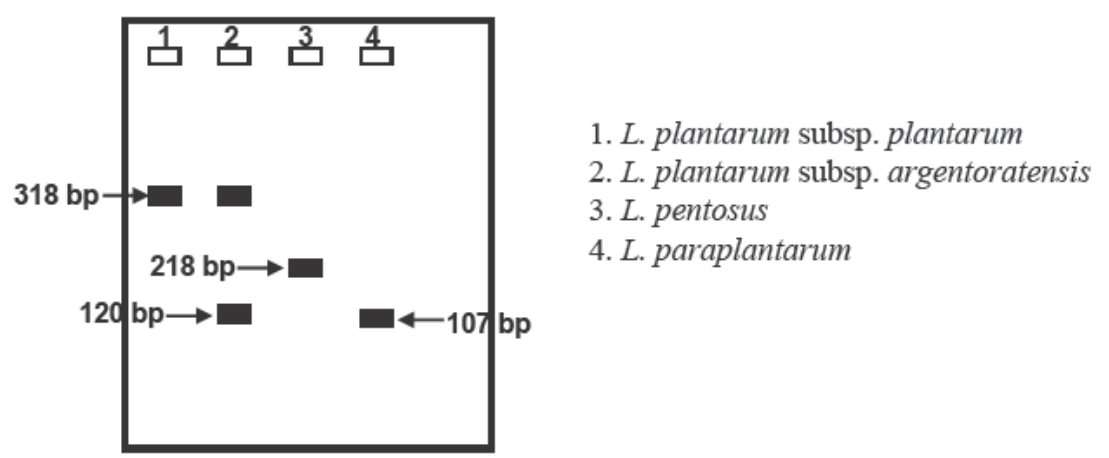

Key E Species-specific primers to differentiate L. casei, $L$ paracasei, L. rhamnosus and L. zeae

\begin{tabular}{cl}
\hline Name of primer & Sequence $\left(5\right.$ ' to $3^{\prime}$ ) \\
\hline W1 & TGCACTGAGATTCGACTTAA \\
W2 & CACCGAGATTCAACATGG \\
W3 & TGCATCTTGATTTAATTTG \\
D1 & TGCATCGTGATTCAACTTAA \\
Y2 & CCCACTGCTGCCTCCCGTAGGAGT \\
\hline
\end{tabular}

L. casei produces a $295 \mathrm{bp}$ of amplicon with W1-Y2 primer set.

L. paracasei produces a $295 \mathrm{bp}$ of amplicon with W2-Y2 primer set.

L. rhamnosus produces a $295 \mathrm{bp}$ of amplicon with W3-Y2 primer set.

L. zeae produces a 295 bp of amplicon with D1-Y2 primer set.

FIGURE 3 (continued)

Key phenotypic characteristics to differentiate malolactic bacteria. 
Lactobacillus sakei subsp. carnosus: R 14b/a, CCUG 31331, CIP 105422, JCM 11031, LMG 17302.

\section{Lactobacillus vini: DSM 20605, CECT 5924}

Lactobacillus zeae: ATCC 15820, CCUG 35515, DSM 20178, JCM 11302, LMG 17315, NCIMB 9537.

\section{Enrichment and isolation}

The most common medium used to isolate Lactobacillus spp. is MRS agar (De Man et al., 1960) or APT agar (Evans and Niven, 1951). Acetate medium (Rogosa et al., 1951) may also be used, but is as MRS and APT, not completely selective. Other LAB such as leuconostocs, pediococci, enterococci and Weissella spp., bifidobacteria and yeasts may also grow. Growth of yeast is prevented by the addition of cycloheximide $(100 \mathrm{mg} / \mathrm{L})$. Intestinal lactobacilli are commonly isolated on MRS, SL, or LAMVAP agar (Hartemink et al., 1997). More anaerobic species may be isolated by supplementing the growth media with L-cysteine $(0.05 \%, \mathrm{w} / \mathrm{v})$ and incubation in an anaerobic jar. In some cases, medium have been supplemented with grape must, tomato juice, fresh yeast extract, malt extract, ethanol, mevalonic acid, beer, fruit juices, cheese whey, or meat extract. It may be necessary to replace glucose with fructose, maltose, sucrose, or arabinose, especially for isolation of heterofermentative lactobacilli. Homohiochii Medium (Kleynmans et al., 1989) and NBB medium (Back, 1980) are good examples of specialised growth media. Plates should always be incubated anaerobically, or in the presence of $10 \% \mathrm{CO}_{2}$ and $90 \% \mathrm{~N}_{2}$ or $\mathrm{H}_{2}$. Carr et al. (2002) compiled an extensive literature survey on culture media for Lactobacillus and other LAB.

\section{LITERATURE CITED}

Back, W., 1980. Bierschädliche Bakterien. Nachweis und Kultivierung bierschädlicher Bakterien im Betriebslabor. Brauwelt 120, 1562-1569.

Bae, S., Fleet, G.H. \& Heards, G.M., 2006. Lactic acid bacteria associated with wine grapes from several Australian vineyards. J. Appl. Microbiol. 100, 712-727.

Barney, M., Volgyi, A., Navarro, A. \& Ryder, D., 2001. Riboprinting and 16S rDNA gene sequencing for identification of brewery Pediococcus isolates. Appl. Environ. Microbiol. 67, 553-560.

Barros, R.R., Carvalho, M.D.S., Peralta, J.M., Facklam, R.R. \& Teixeira, L.M., 2001. Phenotypic and genotypic characterization of Pediococcus strains isolated from human clinical sources. J. Clin. Microbiol. 39, 1241-1246.

Bartowsky, F.J. \& Henschke, P.A., 2004. The "buttery” attribute of wine - diacetyl - desirability, spoilage and beyond. Int. J. Food Microbiol. 96, 235-252.

Björkroth, J. \& Holzapfel, W., 2003. Genera Leuconostoc, Oenococcus and Weissella. In: Dworkin, M., Falkow, S., Rosenberg, E., Schleifer, K.-H. \& Stackebrandt, E. (eds). The prokaryotes (3rd ed.). Springer-Verlag, New York. http://link.springer-ny.com/link/service/books/10125/.

Björkroth, J., Holzapfel, W.H. \& Dicks, L.M.T., 2009. Genus III. Weissella Collins, Samelis, Metaxopoulos and Wallbanks 1994, 370VP (Effective publication: Collins, Samelis, Metaxopoulos and Wallbanks 1993, 597). In: De Vos, P., Garrity, G., Jones, D., Krieg, N.R., Ludwig, W., Rainey, F.A., Schleifer, K-H. \& Whitman, W.B. (eds). Bergeys Manual of Systematic Bacteriology, vol. 3. Springer, New York

Bringel, F., Castioni, A., Olukoya, D.K., Felis, G.E., Torriani, S. \& Dellaglio, F., 2005. Lactobacillus plantarum subsp. argentoratensis subsp. nov., isolated from vegetable matrices. Int. J. Syst. Evol. Microbiol. 55, 1629-1634.

Carr, J.G., 1970. Tetrad-forming cocci in ciders. J. Appl. Bacteriol. 33, 371-379.

Carr, F.J., Chill, D. \& Maida, N., 2002. The lactic acid bacteria: A literature survey. Crit. Rev. Microbiol. 28, 281-370.

Cavett, J.J., Dring, G.J. \& Knight, A.W., 1965. Bacterial spoilage of thawed frozen peas. J. Appl. Bacteriol. 28, 241-251.
Cavin, J.F., Prevost, H., Lin, J., Schmitt, P. \& Diviès, C., 1989. Medium for screening Leuconostoc oenos strains defective in malo-lactic fermentation. Appl. Environ. Microbiol. 55, 751-753.

Cavin, J.F., Schmitt, P., Arias, A., Lin, J. \& Diviès, C., 1988. Plasmid profiles in Leuconostoc species. Microbiol. Alim. Nutr. 6, 55-62.

Collins, M.D., Samelis, J., Metaxopoulus, J. \& Wallbanks, S., 1993. Taxonomic studies on some leuconostoc-like organisms from fermented sausages: Description of a new genus Weissella for the Leuconostoc paramesenteroides group of species J. Appl. Bacteriol. 75, 595-603.

Collins, M.D., Williams, A.M. \& Wallbanks, S., 1990. The phylogeny of Aerococcus and Pediococcus as determined by 16S rRNA sequence analysis: description of Tetragenococcus gen. nov. FEMS Microbiol. Lett. 70, 255-262.

Davis C.R., Wibowo, D., Eschenbruch, R., Lee, T.H. \& Fleet, G.H., 1985. Practical implication of malolactic fermentation: A review. Am. J. Enol. Vitic. 36, 290-301.

De Man, J.C., Rogosa, M. \& Sharpe, M.E., 1960. A medium for the cultivation of lactobacilli. J. Appl. Bacteriol. 23, 130-135.

Dellaglio, F., Trovatelli, L.D. \& Sarra, P.G., 1981. DNA-DNA homology among representatives strains of the genus Pediococcus. Zbl. Bakteriol. Mikrobiol. Hyg. 1 Abt. Orig. C 2, 140-150.

Dicks, L.M.T., 1989. A taxonomic study of Leuconostoc oenos. Ph.D. Dissertation, Stellenbosch University, Private Bag X1, 7602 Matieland (Stellenbosch), South Africa.

Dicks, L.M.T., 1995. Relatedness of Leuconostoc species of the Leuconostoc sensu stricto line of descent, Leuconostoc oenos and Weissella paramesenteroides revealed by numerical analysis of total soluble cell protein patterns. Syst. Appl. Microbiol. 18, 99-102.

Dicks, L.M.T., Dellaglio, F. \& Collins, M.D., 1995. Proposal to reclassify Leuconostoc oenos as Oenococcus oeni (corrig.) gen. nov., comb. nov. Int. J. Syst. Bacteriol. 45, 395-397.

Dicks, L.M.T., Fantuzzi, L., Gonzales, F.C., Du Toit, M. \& Dellaglio, F., 1993. Leuconostoc argentinum sp. nov., isolated from Argentine raw milk. Int. J. Syst. Bacteriol. 43, 347-351.

Dicks, L.M.T. \& Holzapfel, W.H., 2009. Genus II. Oenococcus Dicks, Dellaglio and Collins 1995a, 396 ${ }^{\mathrm{VP}}$. In: De Vos, P., Garrity, G., Jones, D., Krieg, N.R., Ludwig, W., Rainey, F.A., Schleifer, K-H. \& Whitman, W.B. (eds). Bergeys Manual of Systematic Bacteriology, vol. 3. Springer, New York.

Dicks, L.M.T., Van Vuuren, H.J.J. \& Dellaglio, F., 1990. Taxonomy of Leuconostoc species, particularly Leuconostoc oenos, as revealed by numerical analysis of total soluble cell protein patterns, DNA base compositions, and DNA-DNA hybridizations. Int. J. Syst. Bacteriol. 40, 83-91.

Dobson, C.M., Deneer, H., Lee, S., Hemmingsen, S., Glaze, S. \& Ziola, B., 2002. Phylogenetic analysis of the genus Pediococcus, including Pediococcus claussenii sp.nov., a novel lactic acid bacterium isolated from beer. Int. J. Syst. Evol. Microbiol. 52, 2003-2010.

Duenas Chasco, H.T., Rodriguez Carvajal, M.A., Mateo, P.T., Franco Rodriguez, G., Espartero, J.L., Irastorza Iribas, A. \& Gil Serrano, A.M., 1997. Structural analysis of the exopolysaccharide produced by Pediococcus damnosus 2.6. Carbohydr. Res. 303, 453-458.

Endo, A. \& Okada, S., 2006. Oenococcus kitaharae sp. nov., a non-acidophilic and non-malolactic-fermenting oenococcus isolated from a composing distilled shochu residue. Int. J. Syst. Evol. Microbiol. 56, 2345-2348.

Endo, A. \& Okada, S., 2008. Reclassification of the genus Leuconostoc and proposals of Fructobacillus fructosus gen. nov., comb. nov., Fructobacillus durionis comb. nov., Fructobacillus ficulneus comb. nov. and Fructobacillus pseudoficulneus comb. nov. Int. J. Syst. Evol. Microbiol. 58, 2195-2205.

Evans, J.B. \& Niven, C.F., 1951. Nutrition of the heterofermentative lactobacilli that cause greening of cured meat products. J. Bacteriol. 62, 599-603.

Fleet, G.H., 2001. Wine. In: Doyle MP, Beuchat LR, Montville TJ (eds) Food Microbiology Fundamentals and Frontiers (2nd ed.) ASM Press, Washington, DC, pp. 747-772.

Franz, C.M.A.P., Vancanneyt, M., Vandemeulebroecke, K., De Wachter, M., Cleenwerck, I., Hoste, B., Schillinger, U., Holzapfel, W.H. \& Swings, J., 2006. Pediococcus stilesii sp. nov. isolated from maize grains. Int. J. Syst. Evol. Microbiol. 56, 329-333. 
Fujii, T., Nakashima, K. \& Hayashi, N., 2005. Random amplified polymorphic DNA-PCR based cloning of markers to identify the beer-spoilage strains of Lactobacillus brevis, Pediococcus damnosus, Lactobacillus collinoides and Lactobacillus coryniformis. J. Appl. Microbiol. 98: 1209-1220.

Garvie, E.I., 1967a. Leuconostoc oenos sp. nov. J. Gen. Microbiol. 48, 431-438.

Garvie, E.I., 1967b. The growth factor and amino acid requirements of species of the genus Leuconostoc, including Leuconostoc paramesenteroides (sp. nov.) and Leuconostoc oenos. J. Gen. Microbiol. 48, 439-447.

Garvie, E.I., 1975. Some properties of gas-forming lactic acid bacteria and their significance in classification. In: Carr, J.G., Cutting, C.V. \& Whiting, G.C. (eds). Lactic Acid Bacteria in Beverages and Food. Academic Press, London. pp. 339-349.

Garvie, E.I., 1984. Leuconostoc mesenteroides subsp. cremoris (Knudsen and Sørensen) comb. nov. and Leuconostoc mesenteroides subsp. dextranicum (Beijerinck) comb. nov. Int. J. Syst. Bacteriol. 33, 118-119.

Garvie, E.I, 1986. Genus Leuconostoc van Tieghem 1878, 198 $8^{\mathrm{AL}}$ emend mut. char. Hucker and Pederson 1930, 66 ${ }^{\mathrm{AL}}$. In: Sneath, P.H.A., Mair, N.S., Sharpe, M.E. \& Holt, J.G. (eds). Bergey's Manual of Systematic Bacteriology, vol. 2. The Williams \& Wilkins Co., Baltimore. Pp. 1071-1075.

Gasser, F. \& Hontebeyrie, M., 1977. Immunological relationships of glucose-6phosphate dehydrogenase of Leuconostoc mesenteroides NCDO 768 (=ATCC 12291). Int. J. Syst. Bacteriol. 27, 6-8.

Gonzalez, C. \& Kunka, B.S., 1986. Evidence for plasmid linkage of raffinose utilization and associated galactose and sucrose hydrolase activity in Pediococcus pentosaceus. Appl. Environ. Microbiol. 51, 105-109.

Haakensen, M., Dobson, C.M., Hill, J.E. \& Ziola, B., 2009. Reclassification of Pediococcus dextrinicus (Coster and White 1964) Back 1978 (Approved Lists 1980) as Lactobacillus dextrinicus comb. nov., and emended description of the genus Lactobacillus. Int. J. Syst. Evol. Microbiol. 59, 615-621.

Hammes, W.P. \& Hertel, C. 2009. Genus I. Lactobacillus Beijerinck 1901, $212^{\mathrm{AL}}$. In: De Vos, P., Garrity, G., Jones, D., Krieg, N.R., Ludwig, W., Rainey, F.A., Schleifer, K-H. \& Whitman, W.B. (eds). Bergeys Manual of Systematic Bacteriology, vol. 3. Springer, New York.

Hartemink, R., Domenech, V.R. \& Rombouts, F.M., 1997. LAMVAB - a new selective medium for the isolation of lactobacilli from faeces. J. Microbiol. Meth. $29,77-84$.

Henick-Kling, T., 1988. Yeast and bacterial control in winemaking. In: Linskens, H.F. \& Jackson, J.F. (eds). Modern Methods of Plant Analysis, new series, vol. 6. Springer-Verlag, Berlin. pp. 276-316.

Holzapfel, W.H., J Björkroth \& Dicks, L.M.T., 2009a. Genus I. Leuconostoc van Tieghem 1878, 198 $8^{\mathrm{AL}}$ emend mut. char. Hucker and Pederson 1930, 66 ${ }^{\mathrm{AL}}$. In: De Vos, P., Garrity, G., Jones, D., Krieg, N.R., Ludwig, W., Rainey, F.A., Schleifer, K-H. \& Whitman, W.B. (eds). Bergeys Manual of Systematic Bacteriology, vol. 3. Springer, New York.

Holzapfel, W.H., Franz, C.M.A.P., Ludwig, W., Back, W. \& Dicks, L.M.T., 2005. Genera Pediococcus and Tetragenocccus. In: Dworkin, M., Falkow, S., Rosenberg, E., Schleifer, K.-H. \& Stackebrandt, E (eds). The Prokaryotes (3rd edn.), An evolving electronic resource for the microbiological community. HYPERLINK http://www.prokaryotes.com. 2005.

Holzapfel, W.H., Franz, C.M.A.P., Ludwig, W. \& Dicks, L.M.T., 2009b. Genus III. Pediococcus Claussen 1903, 68 ${ }^{\mathrm{AL}}$. In: De Vos, P., Garrity, G., Jones, D., Krieg, N.R., Ludwig, W., Rainey, F.A., Schleifer, K-H. \& Whitman, W.B. (eds). Bergeys Manual of Systematic Bacteriology, vol. 3. Springer, New York.

Hoover, D.G., Walsh, P.M., Kolactis, K.M. \& Daly, M.M., 1988. A bacteriocin produced by Pediococcus species associated with a 5.5 MDa plasmid. J. Food Protect. 51, 29-31.

Kleynmans, U., Heinzl, H. \& Hammes, W.P., 1989. Lactobacillus suebicus sp. nov., an obligately heterofermentative Lactobacillus species isolated from fruit mashes. Syst. Appl. Microbiol. 11, 267-271.

Ingraham, J.L., Vaughn, R.H. \& Cooke, G.M., 1960. Studies of the malolactic organisms of Californian wines. Am. J. Enol. Vitic. 11, 1-4.

Jackson, R., 2008 ( $3^{\text {rd }}$ ed.). Wine Science. Academic Press, USA.

Jager, K. \& Harlander, S., 1992. Characterization of a bacteriocin from Pediococcus acidilactici PC and comparison of bacteriocin-producing strains using molecular typing procedures. Appl. Microbiol. Biotechnol. 37, 631-637.

Kelly, W.J., Asmundson, R.V. \& Hopcroft, D.H., 1989. Growth of Leuconostoc oenos under anaerobic conditions Am. J. Enol. Vitic. 40, 272-282.
König, H. \& Fröhlich, J., 2009. Lactic acid bacteria. In: König, H., Unden, G. \& Fröhlich, J. (eds). Biology of Microorganisms on Grapes, in Must and in Wine. Springer-Verlag, Berlin. pp. 3-29.

Kunkee, R.E., 1991. Some roles of malic acid in the malolactic fermentation in wine making. FEMS Microbiol. Rev. 88, 55-72.

Kurzak, P., Ehrmann, M.A. \& Vogel, R.F., 1998. Diversity of lactic acid bacteria associated with ducks. Syst. Appl. Microbiol. 21, 588-592.

Labarre, C., Guzzo, Cavin, J.F. \& Diviès, C., 1996. Cloning and characterization of genes encoding the malolactic enzyme and malate permease of Leuconostoc oenos. Appl. Environ. Microbiol. 62, 1274-1282.

Langston, C.W. \& Bouma, C., 1959. A study of the microorganisms from grass silage. I. The cocci. Appl. Microbiol. 8, 212-222.

Lonvaud-Funel, A., 1999. Lactic acid bacteria in the quality improvement and depreciation of wine. Antonie van Leeuwenhoek 76, 317-331.

Lonvaud-Funel, A. Guilloux, Y. \& Joyeux, A., 1993. Isolation of a DNA probe for identification of glucan-producing Pediococcus damnosus in wines. J. Appl. Bacteriol. 74, 41-47.

Luchansky, J.B., Glass, K.A., Harsono, K.D., Degnan, A.J., Faith, N.G., Cauvin, B., Baccus-Taylor, G., Arihara, K., Bater, B., Maurer, A.J. \& Cassens, R.B., 1992. Genomic analysis of Pediococcus starter cultures used to control Listeria monocytogenes in turkey summer sausage. Appl. Environ. Microbiol. 58, 30533059 .

Manca de Nadraa, M.C., Fariasa, M.E., Pueyoc, E. \& Poloc, M.C., 2004. Protease activity of Oenococcus oeni viable cells on red wine nitrogenous macromolecular fraction in presence of $\mathrm{SO}_{2}$ and ethanol. Food Control 16, 851-854

Martinez-Murcia, A.J. \& Collins, M.D., 1990. A phylogenetic analysis of the genus Leuconostoc based on reverse transcriptase sequencing of 16S rRNA. FEMS Microbiol. Lett. 70, 73-84.

Martinez-Murcia, A.J. \& Collins, M.D., 1991. A phylogenetic analysis of an atypical Leuconostoc: description of Leuconostoc fallax sp. nov. FEMS Microbiol. Lett. 82, 55-60.

Martinez-Murcia, A.J., Harland, N.M. \& Collins, M.D., 1993. Phylogenetic analysis of some leuconostocs and related organisms as determined from largesubunit rRNA gene sequences: assessment of congruence of small- and largesubunit rRNA derived trees. J. Appl. Bacteriol. 74, 532-451.

McDonald, L.C., McFeeters, R.F., Daeschel, M.A. \& Fleming, H.P., 1987. A differential medium for the enumeration of homofermentative and heterofermentative lactic acid bacteria. Appl. Environ. Microbiol. 53, 1382-1384.

Miranda, M., Ramos, A., Veiga-Da-Cunha, M., Loureiro-Dias, M.C. \& Santos, H., 1997. Biochemical basis for glucose-induced, inhibition of malolactic fermentation in Leuconostoc oenos. J. Bacteriol. 179, 5347-5354.

Mora, D., Fortina, M.G., Parini, C., Daffonchio, D. \&. Manachini, P.L., 2000. Genomic subpopulations within the species Pediococcus acidilactici detected by multilocus typing analysis: Relationships between pediocin Ach/PA-1 producing and non-producing strains. Microbiology 146, 2027-2038.

Mora, D., Fortina, M.G., Parini, C. \&. Manachini, P.L., 1997. Identification of Pediococcus acidilactici and Pediococcus pentosaceus based on 16S rRNA and $l d h D$ gene-targeted multiplex PCR analysis. FEMS Microbiol. Lett. 151, 231236.

Mora, D., Parini, C., Fortina, M.G. \& Manachini, P.L., 1998. Discrimination among pediocin AcH/PA-1 producer strains by comparison of pedB and pedD amplified genes and multiplex PCR assay. Syst. Appl. Microbiol. 21, 454-460.

Nielsen, J.C. \& Richelieu, M., 1999. Control of flavour development in wine during and after malolactic fermentation by Oenococcus oeni. Appl. Environ. Microbiol. 65, 740-745.

Nigatu, A., Ahrne, S., Gashe, B.A. \& Molin, G., 1998. Randomly amplified polymorphic DNA (RAPD) for discrimination of Pediococcus pentosaceus and Ped. acidilactici and rapid grouping of Pediococcus isolates. Lett. Appl. Microbiol. 2, 412-416.

Omar, N.B., Ampe, F., Raimbault, M., Guyot, J.-P. \& Tailliez, P., 2000. Molecular diversity of lactic acid bacteria from cassava sour starch (Colombia). Syst. Appl. Microbiol. 23, 285-291.

Pearce, L.E. \& Halligan, A.C., 1978. Cultural characteristics of Leuconostoc strains from cheese starters. Congrilait 20th International Dairy Congress, Paris, France. pp. 520-521. 
Pederson, C.S. \& Albury, M.N., 1955. Variation among the heterofermentative lactic acid bacteria. J. Bacteriol. 70, 702-708.

Radler, F., 1986. Microbial biochemistry. Experientia 42, 884-893.

Rankine, B.C., 1972. Influence of yeast strain and malo-lactic fermentation on composition and quality of table wines. Am. J. Enol. Vitic. 23, 152-158.

Rodriguez, J.M., Cintas, L.M., Casaus, P., Suarez, M.I. \& Hernandez, P.E., 1997. Detection of pediocin PA-1-producing pediococci by rapid molecular biology techniques. Food Microbiol. 14, 363-371.

Rogosa, J., Mitchell, J.A. \& Wiseman, R.F., 1951. A selective medium for isolation and enumeration of oral and fecal lactobacilli. J. Bacteriol. 62, 132-133.

Rozés, N., Arola, L. \& Bordons, A., 2003. Effect of phenolic compounds on the cometabolism of citric acid and sugars by Oenococcus oeni from wine. Lett. Appl. Microbiol. 36, 337-341.

Santos, E.M., Jaime, I., Rovira, J., Lyhs, U., Korkeala, H. \& Björkroth, J., 2005. Characterization and identification of lactic acid bacteria in "morcilla de Burgos". Int. J. Food Microbiol. 97, 285-296.

Satokari, R., Mattila-Sandholm, T. \& Suihko, M.L., 2000. Identification of pediococci by ribotyping. J. Appl. Microbiol. 88, 260-265.

Schütz, M. \& Radler, F., 1973. Das 'Malatenzym' von Lactobacillus plantarum und Leuconostoc mesenteroides. Arch. Mikrobiol. 91, 183-202.

Simpson, P.J., Fitzgerald, G.F., Stanton, C. \& Ross, R.P., 2006. Enumeration and identification of pediococci in powder-based products using selective media and rapid PFGE. J. Microbiol. Meth. 64, 120-125.

Simpson, P.J., Stanton, C., Fitzgerald G.F. \& Ross, R.P., 2002. Genomic diversity within the genus Pediococcus as revealed by randomly amplified polymorphic DNA PCR and pulsed-field gel electrophoresis. Appl. Environ. Microbiol. 68, $765-771$.

Simpson, W.J. \& Taguchi, H., 1995. The genus Pediococcus, with notes on the genera Tetragenococcus and Aerococcus. In: Wood, B.J.B. \& Holzapfel, W.H. (eds). The Genera of Lactic Acid Bacteria, Academic \& Professional. pp. 125172 .

Sneath, P.H.A., Mair, N.S., Sharpe, M.E. \& Holt, J.G., 1986. Bergey's Manual of Systematic Bacteriology. The Williams \& Wilkins Co., Baltimore.
Swiegers, J.H., Bartowsky, E.J., Henschke, P.A. \& Pretorius, I.S. 2005. Yeast and bacteria modulation of wine aroma and flavour. Aus. J. Grape Wine Res. 11, 139173.

Taguchi, H., Ohkochi, M., Uehara, H., Kojima, K. \& Mawatari, M., 1990. KOT medium, a new medium for the detection of beer spoilage lactic acid bacteria. J. Amer. Soc. Brew. Chem. 48, 72-75.

Tamang J.P., Tamang, B., Schillinger, U., Franz, C.M., Gores, M. \& Holzapfel, W.H., 2005. Identification of predominant lactic acid bacteria isolated from traditionally fermented vegetable products of the Eastern Himalayas. Int. J. Food Microbiol. 105, 347-356.

Torriani, S., Felis, G.E. \& Dellaglio, F., 2001. Differentiation of Lactobacillus plantarum, Lactobacillus pentosus, and Lactobacillus paraplantarum by recA gene sequence analysis and multiplex PCR assay with recA gene-derived primers. Appl. Environ. Microbiol. 67, 3450-3454.

Unden \& Zaunmüller, 2009. Metabolism of sugars and organic acids by lactic acid bacteria from wine and must. In: König, H., Unden, G. \& Fröhlich, J. (eds). Biology of Microorganisms on Grapes, in Must and in Wine. Springer-Verlag, Berlin. pp. 135-148

Weiler, H.G. \& Radler, F., 1970. Milchsäurebakterien aus Wein und von Rebenblättern. Zentralbl. Bakteriol. Parasitenkd. Infektionskr. Hyg. Abt. 2 Orig. $124,707-732$.

Whittenbury, R., 1964. Hydrogen peroxide formation and catalase activity in the lactic acid bacteria. J. Gen. Microbiol. 35, 13-26.

Whittenbury, R. 1965. The enrichment and isolation of lactic acid bacteria from plant material. Zentralbl. Bakteriol. Parasitenkd. Infektionskr. Hyg. Abt. 1 Suppl. $1,395-398$.

Whittenbury, R. 1966. A study of the genus Leuconostoc. Arch. Microbiol. 53, 317.

Wibowo, D., Eschenbruch, R., Davis, C., Fleet, G.H. \& Lee, T.H., 1985. Occurrence and growth of lactic acid bacteria in wine - a review. Am. J. Enol. Vitic. 36, 302-312.

Zhang, B., Tong, H. \& Dong, X., 2005. Pediococcus cellicola sp. nov., a novel lactic acid coccus from a distilled-spirit fermenting cellar. Int. J. Syst. Evol. Microbiol. 55, 2167-2170. 